BNL 51313

UC-11

(Environmental Control Technology and

Earth Sciences - TIC-4500)

\title{
MARSHALL ISLANDS: A STUDY OF DIET AND LIVING PATTERNS
}

J.R. Naidu, N.A. Greenhouse, G. Knight, and E.C. Craighead**

July 1980

*P.O. Box 782, Majuro, Marshall Islands

**8 Platt Street, East Norwalk, Connecticut 06855

SAFETY AND ENVIRONMENTAL PROTECTION DIVISION

BROOKHAVEN NATIONAL LABORATORY

UPTON, NEW YORK 11973 


\section{DISCLAIMER}

This report was prepared as an account of work sponsored by an agency of the l'nited States Government. Neither the United States Government nor any agency thereof. nor any of their employees, nor any of their contractors, subcontractors, or their employees, makes any warranty, express or implied, or assumes any legal liability or responsibility for the accuracy, completeness, or usefulness of any intormation, apparatus, product, or process disclosed, or represents that its use would not infringe privately owned rights. Reîerence herein to any specific commercial pt uduct, process, or service by 1rade name, trademark, manufacturer, or otherwise, does not necessarily constitute or imply its endorsement, recommendation, or favoring by the United States Government or any agency, contractor or subcontractor thereof. The views and opinions of authors expressed herein do not necessarily state or teffect those of the United States Government or any agency, contractor or subcontractor thereof.

Printed in the United States of America

$$
\text { Available from }
$$

National Technical Information Service

U.S. Department of Commerce

5285 Port Royal Road

Springfield, VA 22ltil

Price: Printed Copy \$8.00; Microfiche \$3.50 
Marshall Islands: A Study of Diet and Living Patterns

Contents

$\underline{\text { Page }}$

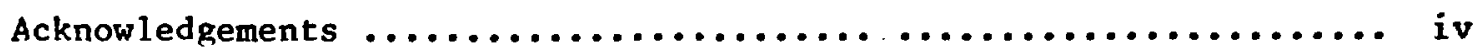

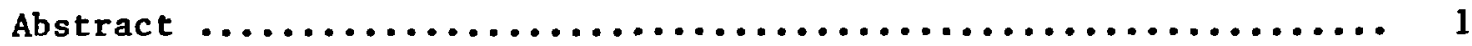

obiective $\ldots \ldots \ldots \ldots \ldots \ldots \ldots \ldots \ldots \ldots \ldots \ldots \ldots \ldots \ldots \ldots \ldots \ldots \ldots \ldots \ldots$

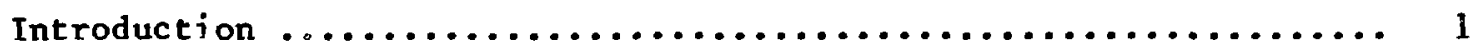

Methods $\ldots \ldots \ldots \ldots \ldots \ldots \ldots \ldots \ldots \ldots \ldots \ldots \ldots \ldots \ldots \ldots \ldots \ldots \ldots \ldots \ldots \ldots \ldots, 2$

Results and Discussions $\ldots \ldots \ldots \ldots \ldots \ldots \ldots \ldots \ldots \ldots \ldots \ldots \ldots \ldots \ldots$

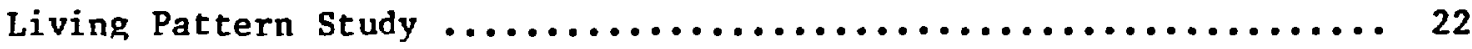

References $\ldots \ldots \ldots \ldots \ldots \ldots \ldots \ldots \ldots \ldots \ldots \ldots \ldots \ldots \ldots \ldots \ldots \ldots \ldots \ldots \ldots \ldots$

Appendices....................................... 29

A. Seasons :

i Local Foods.............................. 30

ii Seasons of the Year......................... 30

B. Marshallese (Local) Foods....................... 34

c. Other Is lands Used for Food Gathering................ 45

D. Data on Edible Portions of Marshallese Foods............. 48

E. Fishes: Types of Fishes and Methods of Fishing.......... 54

F. School Children - Lunch Program.................... 67

G. Typhoon Relief.............................. 70

H. Food Supply Ships - Trip Reports................... 71

I. Private or Community Stores - Types of Foods Available..... 72 


\section{Acknow ledgements}

The authors would like to take this opportunity to express their sincere thanks to the Department of Energy for sponsoring this study as part of the Northern Marshall Islands Radiological Survey.

There are numerous people in the Marshall Islands who have assisted us in providing the necessary information and making our stay in their homes a very happy experience. Their cooperation is gratefully acknowledged.

To the following colleagues who, in spite of their busy schedule, took time to review the report and offered their valuable comments, a sincere note of thanks. The quality of the report has definitely been enhanced through their suggestions: J. Baum, A. Hu11, E. Lessard, C. Meinhold, and R. Miltenberger.

This report was typed by members of the Word Processing group. Their painstaking effort is commended and recognized. 


\title{
Marshall Islands: A Study of Diet and Living Patterns
}

\author{
J.R. Naidu, N.A. Greenhou se, G. Knight* and E.C. Craighead**
}

\author{
Brookhaven National Laboratory, \\ Safety and Environmental Protection Division \\ Upton, New York 11973
}

\section{Abstract}

This study summarizes information on diet and living patterns for the Marshallese. The data was derived from 1 iterature, answers to questionnaires, personal observations while living with the Marshallese for periods extending from months to years, and from direct participation in their activities. The results reflect the complex interactions of many influences, such as, the gathering of local foods, the receipt of food aid through programs, such as, school-1.unch, typhoon-relief, food distributed to populations displaced as a result of nuclear testing, and in recent times the availability of cash for the purchase of imported foods. The results identify these influences and are therefore restricted to local food diets while recognizing that the living patterns are changing as local food gathering is replaced by other food supplies. The data will therefore provide the necessary information for input into models that will assess the radiological impacts attributable to the inhabitation of the Marshall Islands. It is recommended that this study should be continued for at least two to three years in order to more accurately identify trends in local food consumption and living patterns.

\section{objective}

The goal of this study is the evaluation of dietary and living patterns among the inhabitants of the Northern Marshall Islands. These data will be used as input to the dose estimation models (external and internal) that are being developed for the Marshallese who continue to inhabit or will inhabit areas previously contaminated by radioactive fallout from U.S. Pacific Nuclear tests.

\section{Introduction}

This study, by the Safety and Environmental Protection Division (S\&EP) of the Brookhaven National Laboratory, is a continuation of work which began in 1974 as part of environmental monitoring programs for Bikini, Rongelap and Utirik. The Northern Marshall Islands Radiological Survey (NMIRS) of 1978 provided an opportunity to carry out a study in extensive detail, since the role of S\&EP was devoted exclusively to diet and living patterns. Since then, two of the authors, (G. Knight and J.R. Naidu), have continued the study in order to increase the data base obiained through this work. As pointed out in a prelimi-

\footnotetext{
*P.0. Box 782, Majuro, Marshall Islands

**8 Platt Street, East Norwalk, Connecticut 06855
} 
nary report to the NMIRS group, one of the key requirements for reliable data gathering is the isolation of the islanders from the "outside" influence of field trip ships and from scientists conducting environmental or medical studies. This stems from the fact that the Marshallese tend to give such inquires answers which they think are being sought, rather than to provide the objective information desired. Thus the NMIRS program, where in three of the authors spent short periods of time in residence at each island, served to provide a basis for comparisons with past observations, and to establish a foundation for subsequent studies following the NMIRS. These studies have now been extended through 1979 and are expected to continue indefinitely.

Methods

A thorough review of all existing literature was performed (1-6). Earlier studies $(1,2)$ had as their goals the quantitative and qualitative assessments of food intake, and the establishment of its nutrient value. However, it became apparent during the current study that the earlier studies suffered from certain unintended biases which were the result of inquiries made during short field trip visits. We have ascertained that these biases can be minimized by utilizing an observer who has become integrated into the local community to the extent that his or her presence has a negligible impact on community life. The authors of this report have spent periods extending from months to years on the various islands in the Marshalls, during which time they have become an integral part of the island communities, partaking of the local food and participating in (as well as observing) community living patterns. On the basis of this experience, the authors developed a questionnaire which was used to generate much of the dietary information presented in this report.

The generalized information presented in the main body of this report represents a synthesis of the direct observations of the authors, and of the survey data from the questionnaire. Most of the detailed information, which forms the basis for these generalizations, pertains to the following: Islands/Atolls studied, specific aspects of island living patterns, seasonal phenomena, cypes of fish and methods of fishing, edible birds, individual family food consumption patterns, (imported) food subsidy programs, community cooperative store stocks, and satistics on the edible fractions of local foods. All of the above information is included in the Appendices.

The following dietary interview was prepared in an attempt to determine the local diet by posing questions to the islanders themselves. It was taken to a number of communities at Rongelap in Rongelap Atoll, Utirik in Utirik Atoll, Mejit, Ailuk, Wotho, Jabor in Jaliut Atoll, at Killi Island and Majuro.

The questionnaire of the dietary interviews, which is in Marshallese but presented here as a literal English translation, was as follows: 


\section{Marsha!l Islands Dietary Interview}

In answering these questions, please answer in respect to those of your family who presently live at your house and in respect to only those who eat with you every day.

How many people of school age or over are in your family and eat with your family every day?

What is the name of the island where you presently live.

1) How many mature coconuts do you use to prepare coconut milk to mix into your family's food in a typical week?

2) How many mature cocoruts do you grate to mix into your family's food in a typical week?

3) If you are an adult and 18 years or over, other than the mature coconuts mixed into your family's food, how many other coconuts do you eat in a typical week?

4) With respect to your children or brothers and sisters of ages 10 through 18 , other than the mature coconuts mixed in the family's food, how many would you expect one of them to eat in a typical week?

5) If you are an adult, how many drinking coconuts do you consume in a typical week?

6) And if you are an adult, how many of these coconuts that you drink will you also eat the soft meat thereof?

7) With respect to your children or younger siblings of ages 10 through 18 , how many unripe coconuts would you expect one of them to drink in a typical week?

8) And in respect to these children, how many of these unripe coconuts that one of them would drink would you expect him to also eat the meat thereof?

9) If you are an adult, how many of the kenawe coconuts (in a similar fashion as pandanus, the entire husk is sucked and chewed and a considerable portion is eaten) do you eat during a typical month?

10) In respect to your children or younger siblings from ages 10 to 18 , how many of the kenawe coconuts would you expect one child to eat during a typical month?

11) How many of the sprouted coconuts do you cook the iu (haustorium) thereof in preparing traditional dishes to be served at family meals in a typical week?

12) Other than the iu prepared for the family meals, how many iu do you eat in a typical week? 
13) In respect to the children, how many iu does one child eat in a typical week?

14) If you are a man who makes jekaru (Lapped nectar of the coconut flower), how many half-gallon bottlcs does your family use to drink or mix with the family food each day?

15) How many pandanus do you cook and make into pulp to mix with the family food or to preserve into Jankwon in a typical week during pandanus season?

16) Other than the pandanus you mash into pulp, how many will you eat yourself?

17) In respect to the children, on a typical day how many pandanus does one child eat?

18) During breadfruit season, how many of the bukrol or batakatak varieties do you prepare for your family in a typical week?

19) How many of the bukrol or batakatak varieties do you use to preserve into bwido to be eaten by your family during a typical year?

20) During the season for the mejwan variety of breadfuit, how many do you prepare for your family in a typical week?

21) Other than the mejwan you cook for the family, how many of the ripe fruits do you eat in a typical week when this variety of breadfruit is in season?

22) In respect to the children, how many of the ripe fruits do you think one child eats in a typical week?

23) How many of the mejwan variety of breadfruit do you preserve into jankwon for your family to eat during a typical year?

24) Other than the mejwan breadfruit itself, how many nuts of this variety do you eat in a typical week when it is in season?

25) In respect to the children, how many nuts of the mejwan do they eat in a typical week when it is in season?

26) How many blocks of arrowroot starch (about 10 lbs) do you dig and prepare for your family to eat during a typical year?

27) How many (pounds of) fish do you cook during a typical week for your family to eat? (A good sized rijin species weighs about 2 lbs.)

28) How many pumpkins do you cook for your family during a typical year?

29) How many stalks of starch bananas do you cook for your family during a typical year? 
30) How many stalks of sweet bananas does your family eat during a typical year?

31) If you are an adult, how many papayas do you eat during a typical month?

32) In respect to the children, how many papayas would you expect one child to eat during a typical month?

33) How many (pounds of) sweet potatoes do you cook for your family during a typical year?

34) In respect to any other locally grown foods not previously mentioned, please 1 ist the foods and the amount eaten by the family during a typical month or year.

35) How many chickens do you kill and prepare for your family during a typical month or during a typical year?

36) In respect to wild birds, how many times do you make a meal of them during a typical month or year?

37) How many times do you make a meal of pig during a typical month or year?

38) How many times do you eat turtle during a typical month or year?

39) How many times do you eat lobster during a typical month or year?

40) How many times do you eat giant clam during a typical month or year?

41) How many times do you eat the various types of ocean snails during a typical month or year?

42) How many times do you eat octopus during a typical month or year?

43) How many times do you eat the coconut crab during a typical month or year?

44) How many times do you eat clams (other than giant) during a typical month or year?

45) Please circle the months that breadfruit is in season.

$$
\begin{aligned}
& \text { Jan.--- } \\
& \text { Feb.--- } \\
& \text { March-- } \\
& \text { Apri1-- } \\
& \text { May--- } \\
& \text { June--- } \\
& \text { July--- } \\
& \text { Aug.--- } \\
& \text { Sept.-- } \\
& \text { Oct.-- }
\end{aligned}
$$


Nov.---

Dec.---

46) Please circle the months that pandanus is in season.

Jan.---
Feb.---
March--
April--
May----
June---
July---
Aug.---
Sept.--
Oct.---
Nov.---
Dec.---

The feasibility of obtaining a total profile of a typical diet from an interview stems from the prevailing environmental conditions in which the variety of available foods is quite restricted. There is also a very limited trading economy - both the variety and availability of imported foods being restricted by the limited capital of those who import and retail such goods. Thus the limited availability of cash affects both the variety of traditional foods and the amount of contemporary imports as well. Thus, the typical diet is very "day to day". This makes it possible to obtain relatively accurate estimates on a question and answer basis.

Traditionally, one of the most respected talents is the ability to quickly divide large emounts of local food equitably among large numbers of families at island celebrations. The authors have observed the skill of both men and women at this task. Therefore, due to these environmental, economic and cultural factors, it appears that the islanders themselves may eventually produce more accurate estimates of the foods they eat than those likely to be obtained by outside observations.

A crucial problem for an outside observer is that of finding the "typical" family upon which to oase his observations, since individual families consume variable amounts of local foods. Some appear to eat primarily a local diet, while that of others contain many imported foods. An analysis of the individual answers of the interviews shows the scope of this variability. However, observations indicate a large variance about the average which reflects wide variations in personal preferences for foods. This is not to suggest that direct observations, especia'.ly if made during a complete 365 day cycle, would not yield significant results - but only that such results could not be considered "average" unless observations of a large number of individuals were made. Such a study would show a "typical maximum" or "typical minimum" diet of such families, due to the fact that they would represent such extremes from the norm that they would stand out to the observer whereas the "typical average" diet of the normal family does not. Therefore an outside observer would have no way of choosing which typical family to observe. 
The interview data does not provide the "typical average" of the local food consumed by the islanders of the various communities. Rather they provide es imates which approach the "typical average." An interview of forty-four questions cannot provide a direct and straight forward "typical average" of locai food actually consumed. The islanders provide better estimates on food they prepare rather than on food actually eaten. Within the interview, emphasis was placed on the amounts of food prepared for the family on a weekly basis, since this was felt to be the most easily answered question to pose concerning the local diet. Since the Marshallese are by culture food gatherers they know more or less how much food they regularly gather and how much they have to cook to keep their families adequately fed. However, not all the food cooked for the family is eaten. Since there is no refrigeration, an undetermined quantity of left-overs is probably on many occasions wasted or more likely fed to pigs or in some cases chickens. Most families keep a pig or two and at least half the diet of these pigs consists of left-overs. Thus, the present study provides a more usable indication for food cooked but not necessarily eaten by the family.

Another problem in obtaining accurate estimates of food consumption is due to food sharing, which introduces a significant variable into the calculations based on the outside observer and interview methods. Food sharing is a culturally induced readiness to feed not only family members, but anyone present as well. An island society is quite open and islanders roam freely from one house to another at leisure. Thus there is a tendency to prepare a larger amount of food then needed for ones immediate family. The problem then is to estimate the amount of food given away. This is a difficult estimate to make, even for an Islander, as it is by no means a consistent amount. What is known is that the Marshallese cook regular amounts, and that they can provide reasonably accurate estimates on how much they prepare. It is not clear how much of this the family actually consumes. To try and pin the islanders down on this question during an interview is difficult. Every man knows from habit how much food he needs to regularly gather to provide for his family. He can only guess how much of this food he occasionally gives away. It was this circumstance that prompted us to concentrate our interview questions on the amount of food regularly prepared, even though it appears that some portion of this food is given away. In the authors" judgement, it seemed best to start with the most reliable estimates possible, and then to proceed from there with further study and comparison.

It should be noted then that the averages obtained from the answers to the various questions of the interview are in many cases based on food prepared for family members. Such averages are labeled per family member (PFM). They were computed by dividing the total amount of food prepared by all families by the total number of family members associated with the individual adults interviewed. Had each member of the family been interviewed (an obviously important step in future studies) the amount cooked (less the amount wasted) should be roughly equal to the total amount eaten. Thus, the problem of food sharing could have been successfully by-passed. However, due to time limitations, the inability to interview those reluctant to participate, and a concern not to inconvenience the islanders in any way meant that an inclusive study of all family members (which would entail active cooperation at all levels of the government of the Marshall Islands) has yet to be completed. 
Therefore, this attempt to seek estimates from the islanders themselves concerning the actual amounts of local foods in their contemporary diet should be used not as a definitive answer to the question of what constitutes the "typical average." Rather it should be regarded as a feasibility study on the possibility of obtaining the desired information in this way. In the authors' judgement, the averages obtained from the interview study represent overestimates. They should be so considered until such time as further study proves them accurate or (more $l i k e l y$ ) provides representative estimates of food sharing and wastage, which could be folded into the study to provide more accurate consumption estimates. Until such time as the factors involved are more thoroughly understood, the feasibility of obtaining a "typical average" estimate from the interview method is in question. However, the present study establishes an upper limit, which has been confirmed by (a) an estimate of the calorie intake based on calorie value of foods $(1,2)$, and (b) the quantity of food that is available and is gathered on the islands.

\section{Results}

The data obtained from the interviews and observations made by the authors since 1970 suggests that the diet patterns can be divided into three typical categories or communities. These communities have the following characteristics:

Community A:

a. Maximum availability of local foods

b. Highly depressed local economy - living within income provided by selling copra

c. Low population

d. Little or no ability to purchase imported food

Community B:

a. Low availability of local foods - except fish (which can form as much as $33 \%$ of the total diet as a result of excellent fishing in the area).

b. Overpopulated - resulting in low per capita availability of local foods.

c. A good supply of imported foods (supply boat comes in every two to three weeks) along with the availability of jobs.

\section{Community C:}

a. Low availability of local foods, even the fishing is poor

b. Large government food program 
c. Overpopulated

d. A good supply of imported foods and availability of cash to buy them.

The results of the interviews and observations are therefore categorized according to the three communities defined above and are tabulated as follows:

Table - 1: For Community A indicating the quantities of local foods consumed

Table - 2: For Community B indicating the quantities of local foods consumed

Table - 3: For Community $C$ indicating the quantities of local foods consumed

Results and Discussion

One of the most significant results of the dietary interview was the determination of the relative portions of local foods in the islander's diet. Tables 1 to 3 show that the amounts of local foods prepared and eaten varies considerably in each community, but that the relative proportions of the local foods which are prepared and eaten are strikingly consistent, regardless of the respective availability of imported foods in each of the three communities. With respect to imported foods, Community (A) was chosen on the basis of low availabi1ity. All islanders of this community are primarily copra producers and retain their traditional food gathering lifestyle in an area of correspondingly maximum local food availability. Community (B) was chosen because of high availability of imported fooas due to the presence of a well stocked co-op store and the proliferation of government jobs. No copra is made at community (B) and as noted elsewhere in the Marshall Islands the development of a "westernized" economy results (primarily due to the limited land area) in a corresponding minimizing of local food availability. Community (C) was chosen for its large food subsidy and the low availability of local foods resulting from high population density. It is assumed that imported foods are highly available at (C), moderately avai1able at (B) and of limited availability at (A). From Tables 1, 2 and 3 it appears that the consumption of 1 ocal foods is $100 \%$ for Comnunity A, $33 \%$ for Community $B$ and $25 \%$ for Community $C$, of the total diet (local and imported food). There is a tendency for the islanders to prepare and cook less local food as imported foods become more and more available. Nevertheless, the relative portions of the local foods eaten appear to remain constant regardless of the availability of imported foods either from a "westernized" economy or a food subsidy program. This is dramatically evident when we compare the amount of coconuts (iri all stages of growth and in the different modes of preparation) consumed, for example, they constitute: $55 \%$ of total 1 ocal diet in Community (A), $58 \%$ in Community (B) and $47 \%$ in Community (C). The relative portions of the various other local foods seems only to change significantly due to environmental conditions. For instance, the fishing at community (B) is widely reputed to be the best in the Marshalls. This explains why $f$ ish accounts for $36 \%$ of the local diet at (B) as compared to $29 \%$ at (A); whereas the islanders at (C) (where there exists limited opportunity for fishing) estimate fish to be only $19 \%$ of the 
local food they prepare for their families to eat. It may therefore be concluded that the local diet is basically quite uniform and that it changes primarily due to environmental conditions. The effect of imported food is not so much to change the elements of the local diet bi:c simply to reduce them proportionately. The only exceptions to this tendency towards proportionate over-all reduction are Jekaru (coconut sap), Mokmok (arrowroot), and Jankwon (preserved mejwan breadfruit and preserved pandanus). This may be due to the intense labor involved in the processing and preparation of these three foods. They appear to be the first traditional foods to be replaced from a total local food diet by imported sugar, rice and flour. However. further studies are needed to conclusively demonstrate this.

With respect to community (A) where estimates showed the food prepared and eaten to be nearly $100 \%$ of the total diet, it is clear that these estimates exceed the actual amount that could conceivably be consumed, even by all the family members. This is especially so considering the fact that this group of family members includes women and children who could not possibly consume all that food on a daily basis when we know that they are eating significant quantities of imported foods as well.

Table $4 \mathrm{~A}$ and $4 \mathrm{~B}$ represent a typical maximum diet. It represents the most conservative estimate on the total gram weights of the various local foods which could conceivably be consumed under the assumption of a $100 \%$ local diet.

These estimates are based on the assumption that ail the Mirshallese Iiving on outer islands regulate their dietary habits to a certail extent 0 a pattern parallel to environnental conditions and the natural food gathering cycles that are governed by these conditions. It is based on a general observation that most islanders do eat local foods. These estimates also indicate how much of a particular food is eaten (by a typical adult and child) during a given foods' peak season or seasons. They do not consider those periods when a particular food is scarce or otherwise difficult to obtain. Since these estimates are based on a cycle of one year, it seems reasonable to assume that this method could provide an estimated maximum. It has also the advantage of being based on principles and assumptions which are scientifically verifiable. The various srowing seasons are subject to yearly change. Also the length and production of each growing season varies somewhat from year to year. In calculating the maximum diet the tabulations reflect a somewhat higher percentage of jekaro, coconut and pandanus than could reasonably be expected.

It should be noted that an individual cxisting totally on such a diet would have to be carrying out a very active food gathering existence, and would therefore have very little time for other endeavors. In short, he would have to return to the premodernized state his ancestors were living 200 years ago. It should also be noted that a higher maximum consumption of any one type of food is conceivable though it would be unlikely for two reasons. One, is the fact that the premodern Marshallese society as well as the contemporary society is very communal in its food consumption patterns. This means that food sharing is extremely important, and therefore if any one person gathers a great deal of any one particular type of food, he is more likely to divide it up and give it away 
Table 1: Community A

\begin{tabular}{c} 
Interview \\
Question \\
No. \\
\hline \\
\hline 1 \\
2 \\
3 \\
4 \\
5 \\
6 \\
7 \\
8 \\
9 \\
10 \\
11 \\
12 \\
13 \\
14 \\
15 \\
16 \\
17 \\
18 \\
18 \\
19 \\
20 \\
21 \\
22 \\
23 \\
24 \\
25 \\
26 \\
27 \\
28 \\
29 \\
30 \\
31 \\
32 \\
33 \\
34 \\
35 \\
36 \\
37 \\
38 \\
39 \\
40 \\
41 \\
42 \\
43 \\
44 \\
\end{tabular}

\begin{tabular}{|c|c|}
\hline $\begin{array}{c}\text { grams / } \\
\mathrm{yr} \\
\end{array}$ & $\begin{array}{c}\text { mame for } \\
\text { food }\end{array}$ \\
\hline 9984 & el \\
\hline 24960 & Waini \\
\hline 64896 & Waini \\
\hline 57408 & Waini \\
\hline 374348 & drenin ni \\
\hline 94640 & Medi \\
\hline 334880 & drenin ni \\
\hline 114244 & Medi \\
\hline 8320 & Kenawe \\
\hline 11960 & Kenawe \\
\hline 71760 & iu \\
\hline 121680 & $\mathrm{iu}$ \\
\hline 90480 & iu \\
\hline 137592 & Jekaru \\
\hline 11700 & Jankwon \\
\hline 49896 & Bob \\
\hline 51912 & Bob \\
\hline 27500 & Batakatak or \\
\hline 16500 & (Bukrol) \\
\hline 30000 & (Bukrol) \\
\hline 17952 & Me jwan \\
\hline 4320 & Me jwan \\
\hline 1890 & Me jwan \\
\hline 3000 & Me jwan \\
\hline 1488 & Kole Nut \\
\hline 1578 & Kole Nut \\
\hline 1946 & mokmok \\
\hline 160368 & ik \\
\hline 2000 & punki \\
\hline 7500 & binana \\
\hline 7500 & binana \\
\hline 12120 & kanapu \\
\hline 12600 & kanapu \\
\hline 364 & potato \\
\hline 7182 & local vegetable food \\
\hline 500 & bao lol \\
\hline 2037 & bao lin \\
\hline 850 & pik \\
\hline 1000 & won \\
\hline 500 & wor \\
\hline $\begin{array}{r}750 \\
400\end{array}$ & $\begin{array}{l}\text { kabor } \\
\text { jerol }\end{array}$ \\
\hline $\begin{array}{r}11400 \\
913\end{array}$ & kwid \\
\hline 4500 & barolab \\
\hline 2150 & clams \\
\hline
\end{tabular}

English

coconut grated for coconut milk

coconut ripe for copra

coconut ripe for copra

coconut ripe for copra

coconut water

tender coconut meat

coconut water

tender coconut meat

coconut variety-can be eaten raw coconut variety-can be eaten raw coconut 'apple'

coconut 'apple'

coconut 'apple'

nectar from soconut bud

pandanus pulp

pandanus

pandanus

breadfruit different variety

breadfruit different variety

breadfruit different variety

breadfruit with seeds

breadfruit with serids

breadfruit with s'eds

breadfruit with seeds

seeds of breadiruit

seeds of bresdfruit

arrowroot

fish

pumpkin

banana

banana

papaya

weet potatoe

ocal vegetable foods

poultrv

wild bird

pork

turtle

turtle

giant clams

snails

oc toous

coconut crab

clams (small) 
Table 2: Community B

\begin{tabular}{c} 
Interview \\
Question \\
No. \\
\hline \\
\hline 1 \\
2 \\
3 \\
4 \\
5 \\
6 \\
7 \\
8 \\
9 \\
10 \\
11 \\
12 \\
13 \\
14 \\
15 \\
16 \\
17 \\
18 \\
19 \\
20 \\
21 \\
22 \\
23 \\
24 \\
25 \\
26 \\
27 \\
28 \\
29 \\
30 \\
31 \\
32 \\
33 \\
34 \\
35 \\
36 \\
37 \\
38 \\
39 \\
40 \\
41 \\
42 \\
43 \\
44 \\
\end{tabular}

\begin{tabular}{|c|c|}
\hline $\begin{array}{l}\text { grams / } \\
\text { weeks }\end{array}$ & $\begin{array}{l}\text { No, of } \\
\text { weeks }\end{array}$ \\
\hline 49.4 & 52 \\
\hline 264 & 52 \\
\hline 216 & 52 \\
\hline 144 & 52 \\
\hline 3611 & 52 \\
\hline 702 & 52 \\
\hline 2300 & 52 \\
\hline 416 & 52 \\
\hline 0.25 & 52 \\
\hline 0.5 & 52 \\
\hline 350 & 52 \\
\hline 700 & 52 \\
\hline 830 & 52 \\
\hline - & - \\
\hline 1200 & 13 \\
\hline 2688 & 13 \\
\hline 1680 & 13 \\
\hline 450 & 12 \\
\hline - & - \\
\hline 245 & 12 \\
\hline 380 & 8 \\
\hline 272 & 8 \\
\hline - & - \\
\hline $\begin{array}{l}18.3 \\
40.8\end{array}$ & $\begin{array}{l}8 \\
8\end{array}$ \\
\hline- & - \\
\hline 1364 & 52 \\
\hline
\end{tabular}

weekly consumption not possible to deteruitue as such only annual figures given.

\begin{tabular}{|c|c|}
\hline $\begin{array}{c}\text { grams / } \\
y r \\
\end{array}$ & $\begin{array}{c}\text { Marshallese } \\
\text { name for } \\
\text { food }\end{array}$ \\
\hline 2569 & E1 \\
\hline 13728 & Naini \\
\hline 11232 & Waini \\
\hline 7488 & Wain $\mathrm{i}$ \\
\hline 187772 & drenin $n$ \\
\hline 36504 & Medi \\
\hline 119600 & drenin ni \\
\hline 21632 & Medi \\
\hline 13 & Kenawe \\
\hline 26 & Kenawe \\
\hline 18200 & iu \\
\hline 36400 & i u \\
\hline 43160 & iu \\
\hline- & jakaru \\
\hline 15600 & Makon (jankwon) \\
\hline 34944 & Bob \\
\hline 21840 & Bob \\
\hline 5400 & Bukrol or \\
\hline 1750 & Batakatak \\
\hline 2940 & Me jwan \\
\hline 3040 & Me jwan \\
\hline 2176 & Me jwan \\
\hline - & Me jwan \\
\hline 146 & kole nut \\
\hline 326 & kole nut \\
\hline - & mokmok \\
\hline 70928 & ik \\
\hline- & punki \\
\hline 2800 & binana \\
\hline 4000 & binana \\
\hline - & kanapu \\
\hline - & kanapu \\
\hline - & potato \\
\hline - & local vegetable foods \\
\hline 1200 & bao lol \\
\hline 3250 & bao lin \\
\hline 500 & pik \\
\hline 41 & won \\
\hline 50 & wor \\
\hline 4250 & kabor \\
\hline 4250 & jerol \\
\hline 7125 & kwid \\
\hline 350 & barolab \\
\hline 1075 & clams \\
\hline
\end{tabular}

English equivalent

coconut grated for coconut milk coconut ripe for copra cocont ripe for copra coconut ripe for copra coconut water

tender coconut meat

coconut water

tender coconut meat

coconut variety-can be eaten raw coconut variety-can be eaten raw coconut 'apple'

coconut 'apple'

coconut 'apple'

nectar from coconut bud

pandanus pulp

pandanus

pandanus

breadfruit different variety

breadfruit with seed

breadfruit with seed

breadfruit with seed

breadfruit with seed

seeds of breadfruit

seeds of breadfruit

arrowroot

fish

pumpl in

banana

banana

papaya

papaya

sweet potatoe

local vegetable foods

poultry

wild birds

pork

turtle

lobster

giant clam

snails

octopus

coconut crab

clams (small) 
Table 3: Community $\mathrm{C}$

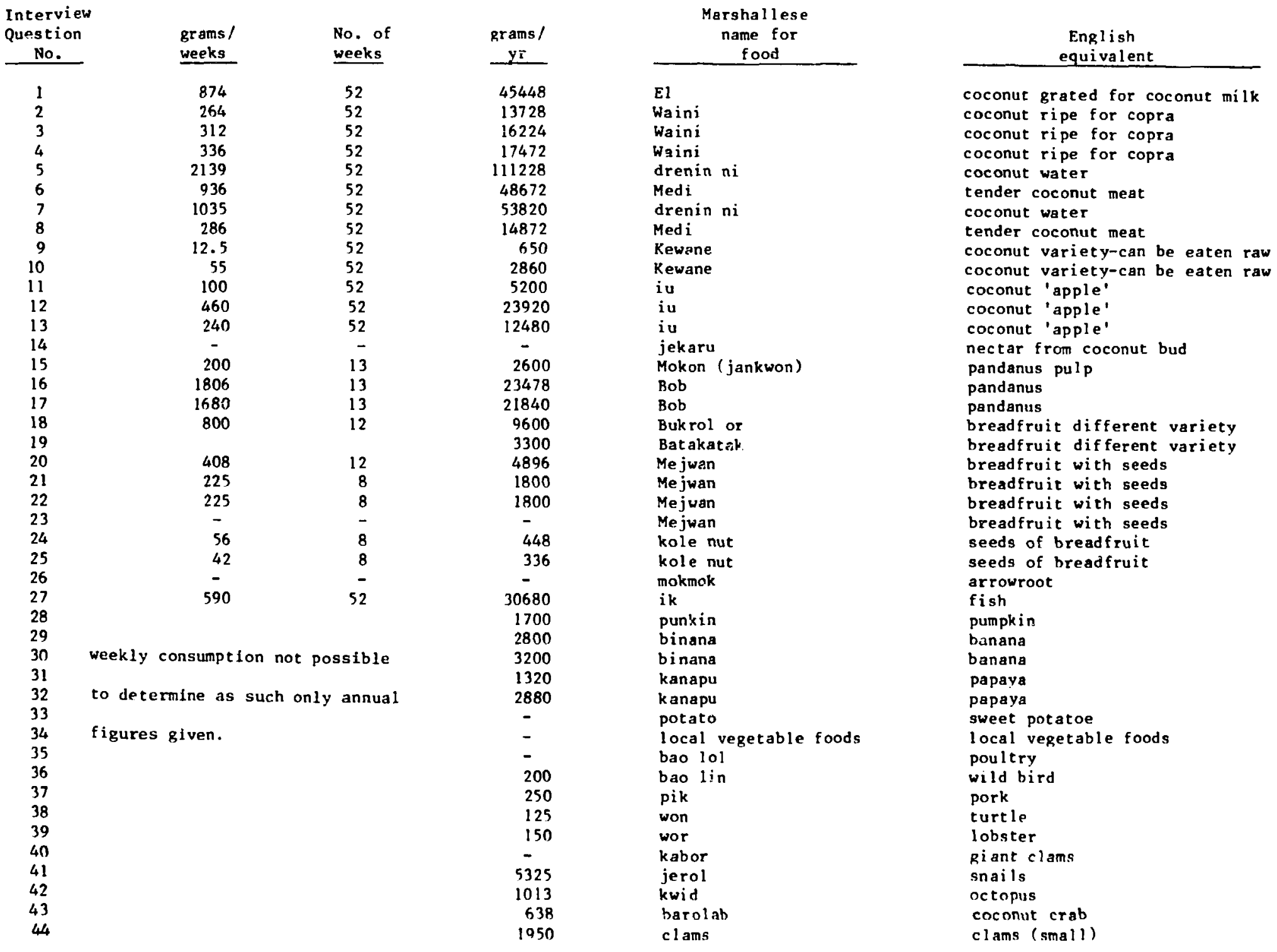


TABLE 4A: MAXIMUM DIET FOR LOCAL FOODS - FOR ADULT MAIRS
WEEK NO. STARTING FROM JNNURY AND THEREFORE REPRESENTS SEASONS AS WELL

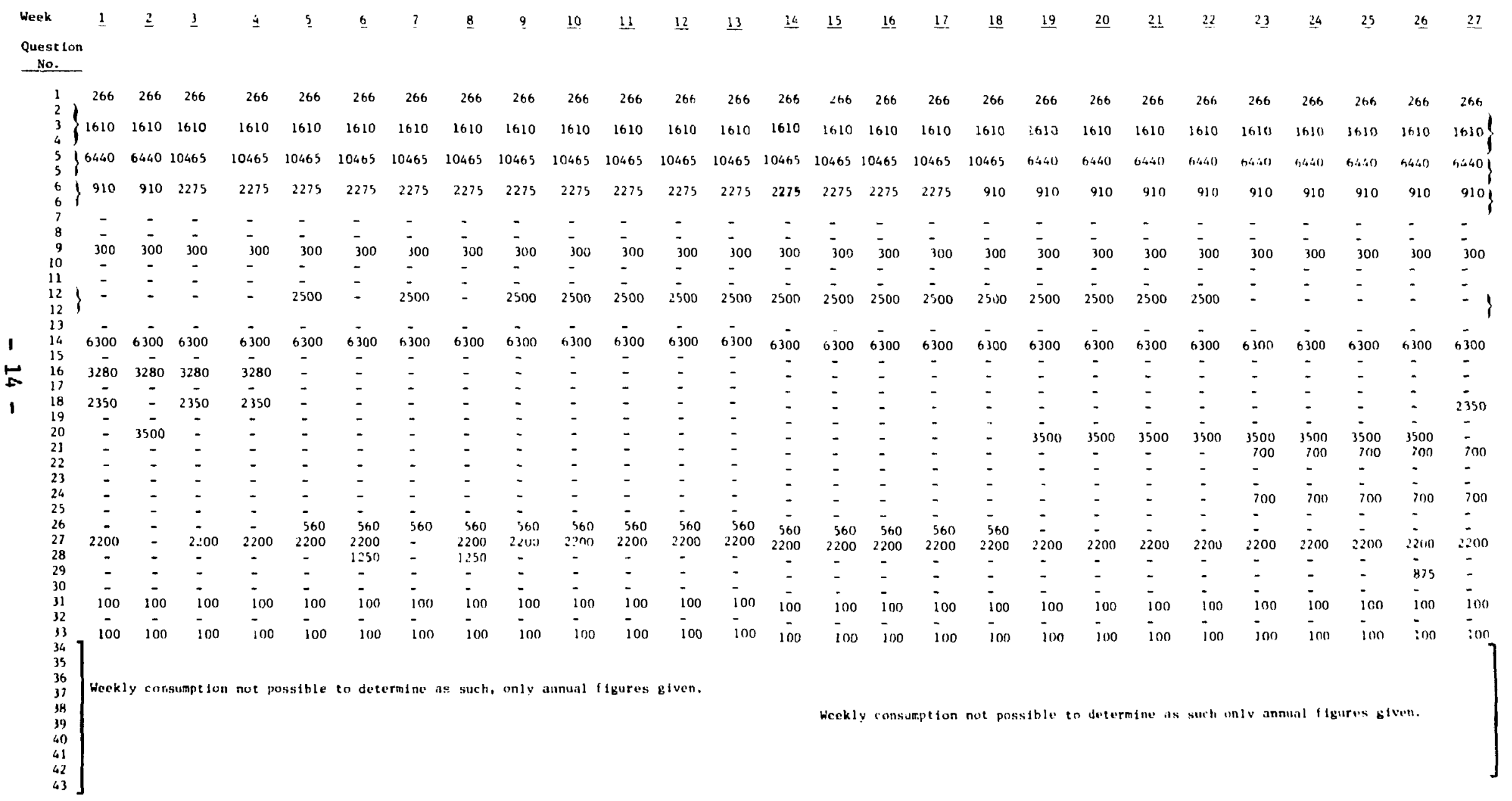


TABLE 4A : MAXINOM DIET FOR LOCAL FOODS - FOR ADULT MALES

WEEK NO. STARTING FROM JANUARY AND THEREFORE REPRESENTS SEASONS AS WELL

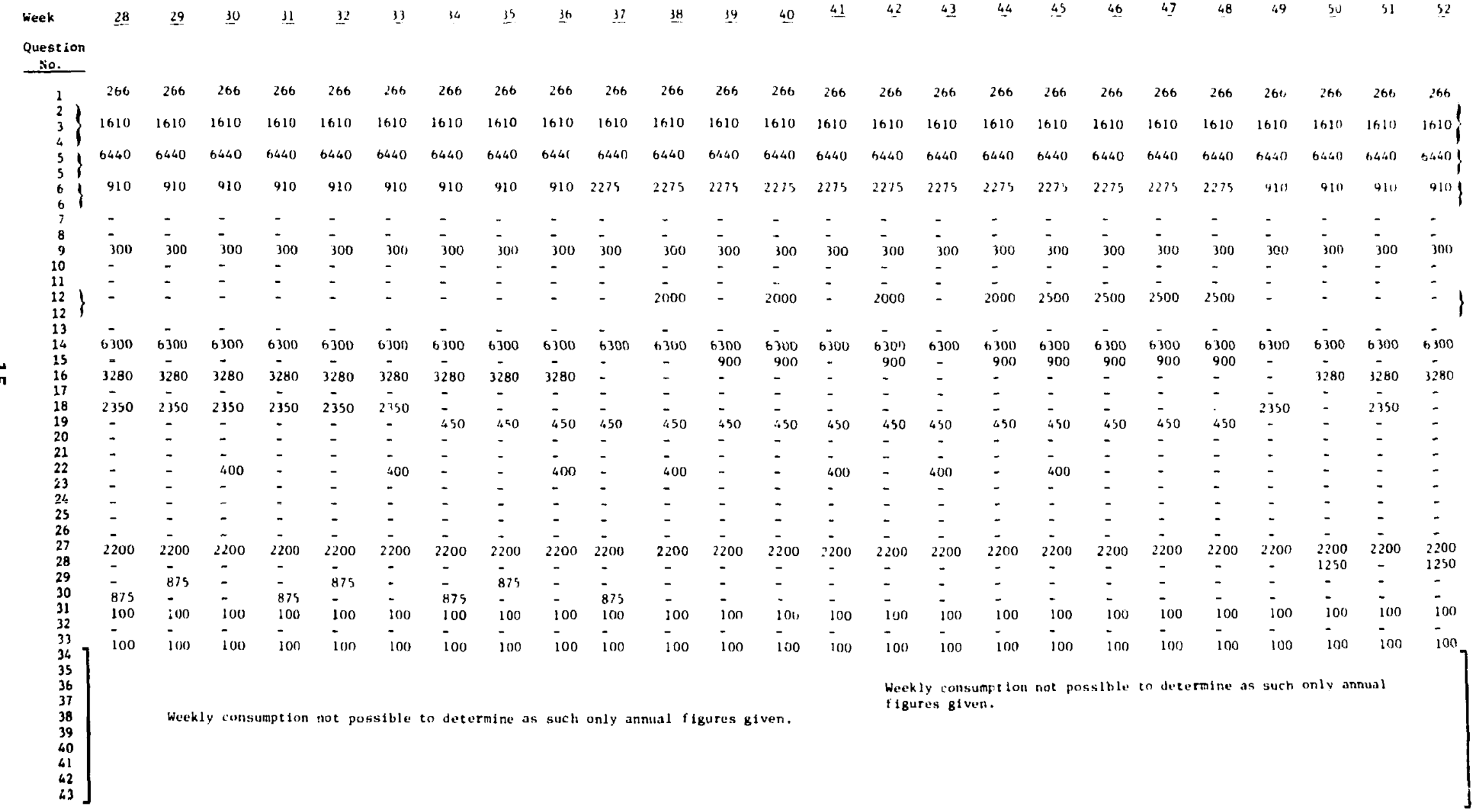


Table 4B: Summary of Maximum Diet (Annua! Consumption)

\begin{tabular}{|c|c|c|c|c|c|}
\hline $\begin{array}{c}\text { Question } \\
\text { No. }\end{array}$ & $\begin{array}{c}\text { Grams/ } \\
\text { Heek }\end{array}$ & $\begin{array}{c}\text { No. } \\
\text { Weeks }\end{array}$ & $\begin{array}{c}\text { Grams/ } \\
\text { Year }\end{array}$ & Marshallese & English \\
\hline 1 & 266 & 52 & 13832 & EL & coconut graated for coconut milk \\
\hline 2 & & & & Waini & coconte ripe for copra \\
\hline 3 & 1610 & 52 & 83720 & Waini & coconut ripe for copra \\
\hline 4 & & & & Waini & coconut ripe for copra \\
\hline 5 & 6440 & 36 & 231840 & drenin ni & coconut water \\
\hline 5 & 10465 & 16 & 167440 & drenin ni & coconut water \\
\hline 6 & 910 & 25 & 22750 & Medi & tender coconut meat \\
\hline 6 & 2275 & 27 & 61425 & Medi & tender coconut meat \\
\hline 7 & - & - & - & drenin ni & coconut water \\
\hline 8 & - & - & - & Medi & tender coconut meat \\
\hline 9 & 300 & 52 & 15600 & Kenawe & coconut variety-can be eaten raw \\
\hline 10 & - & - & - & Kenawe & coconut varietu-can be eaten raw \\
\hline 11 & - & - & - & iu & coconist 'apple' \\
\hline 12 & 2000 & 4 & 8000 & iu & coconut 'apple' \\
\hline 12 & 2500 & 20 & 50000 & iu & coconut 'apple' \\
\hline 13 & - & - & - & iu & coconut 'apple' \\
\hline 14 & 6300 & 52 & 327600 & jekaru & nectar from coconut bud \\
\hline 15 & 900 & 8 & 7200 & Makon (jankwon) & pandanus pulp \\
\hline 16 & 3280 & 16 & 52480 & Bob & pandanus \\
\hline 17 & - & - & - & Bob & pandanus \\
\hline 18 & 2350 & 12 & 28200 & Bukrol or & breadfruit different variety \\
\hline 19 & 450 & 15 & 6750 & Batakatak & breadfruit different varietv \\
\hline 20 & 3500 & 9 & 31500 & Me jwan & breadfruit with seed \\
\hline 21 & 700 & 5 & 3500 & Me jwan & breadfruit with seed \\
\hline 22 & 400 & 7 & 2800 & Me jwan & breadfruit with seed \\
\hline 23 & - & - & - & Me jwan & breadfruit with seed \\
\hline 24 & 700 & 5 & 3500 & kole nut & seeds of breadfruit \\
\hline 25 & - & - & - & kole nut & seeds of breadfruit \\
\hline 26 & 560 & 14 & 7800 & mokmok & arrowroot \\
\hline 27 & 2200 & 50 & 110000 & ik & fish \\
\hline 28 & 1250 & 4 & 5000 & punki & pumpk in \\
\hline 29 & 875 & 4 & 3500 & binana & banana \\
\hline 30 & 875 & 4 & 3500 & binana & banana \\
\hline 31 & 100 & 52 & 5200 & kanapu & papaya \\
\hline 32 & - & - & - & kanapu & papaya \\
\hline 33 & 100 & 52 & 5200 & potato & sweet potatoe \\
\hline 34 & & & - & local vegetable foods & local vegetable foods \\
\hline 35 & \multirow{2}{*}{\multicolumn{2}{|c|}{ week 1 y consumption not }} & 4375 & bao lol & poult:-y \\
\hline 36 & & & 1750 & bao 1 in & wild bird \\
\hline 37 & \multicolumn{2}{|c|}{ possible to determine } & 3500 & pik & pork \\
\hline 38 & \multirow{3}{*}{\multicolumn{2}{|c|}{ as such only annual }} & 1750 & won & turtle \\
\hline 39 & & & 7000 & wor & lobster \\
\hline 40 & & & 7000 & kabor & giant clam \\
\hline 41 & \multirow{3}{*}{\multicolumn{2}{|c|}{ figures given. }} & 8679 & jerol & snails \\
\hline 42 & & & 5250 & kwid & octopus \\
\hline 43 & & & 7000 & barolab & coconut crab \\
\hline
\end{tabular}


rather than consume a large portion of it himself. Second, the acceptance of food offered is also a very important part of the culture, and therefore it would be very difficult for an individual to isolate his food gathering and consumption patterns from those of the society at large. This latter point is especially true for foods which have limited availability, such as, breadfruit, pump$k i n$, papaya, tananas, potatoes and during certain times, pandanus and $f$ ish. Coconuts and jekaru on the other hand can be gathered in significant quantities at all times. It is therefore much more likely that a maximum (a totally local) diet would be based on them.

If it is assumed that Tables $4 \mathrm{~A}$ and $4 \mathrm{~B}$ represent the maximum amount of local foods consumed, and that whatever imported food is eaten will have a tendency to displace proportionate amounts of local foods, then in principle a "typical average" diet could be established. This could be done by subtracting the caloric content of imported food from the total calories of local food consumed per year as shown on the maximum table, and then converting the difference to gram weights using calorie to gram conversion factors for the local foods. By using this method, one can derive the typical amount of local food that could be expected to be consumed in addition to the imported food eaten. Table 5 derives this diet pattern and also presents the averages for the different age groups and sexes.

In sumary the results of the study establish maximum estimates of the consumptior of local foods, based on the amount of local food that an islander living a traditional 1 ife and a totally local diet could consume. These estimates could be further refined by the use of calorie conversion factors specific to the Marshall Islanders and specific to the local food they consume. With reference to the contemporary diet or "typical average" we are continuing our study in two ways. One is by the utilization of the interview method in an attempt to determine the full range of local food consumption in combination with studies of food wasting and food sharing. A second is by the determination of the quantity of imported food consumed in these same communities. In other words, we are suggesting a double approach which would attempt to determine the coutemporary diet from opposite directions. This could produce either two corresponding figures or more likely, two reliable figures between which the contemporary or "typical average" diet of the islanders in the community in question would lie. 
Table 5: Typical Average nirt as a Function of Age and Sex in Comparianon to the Maximum Diet (g/yr).

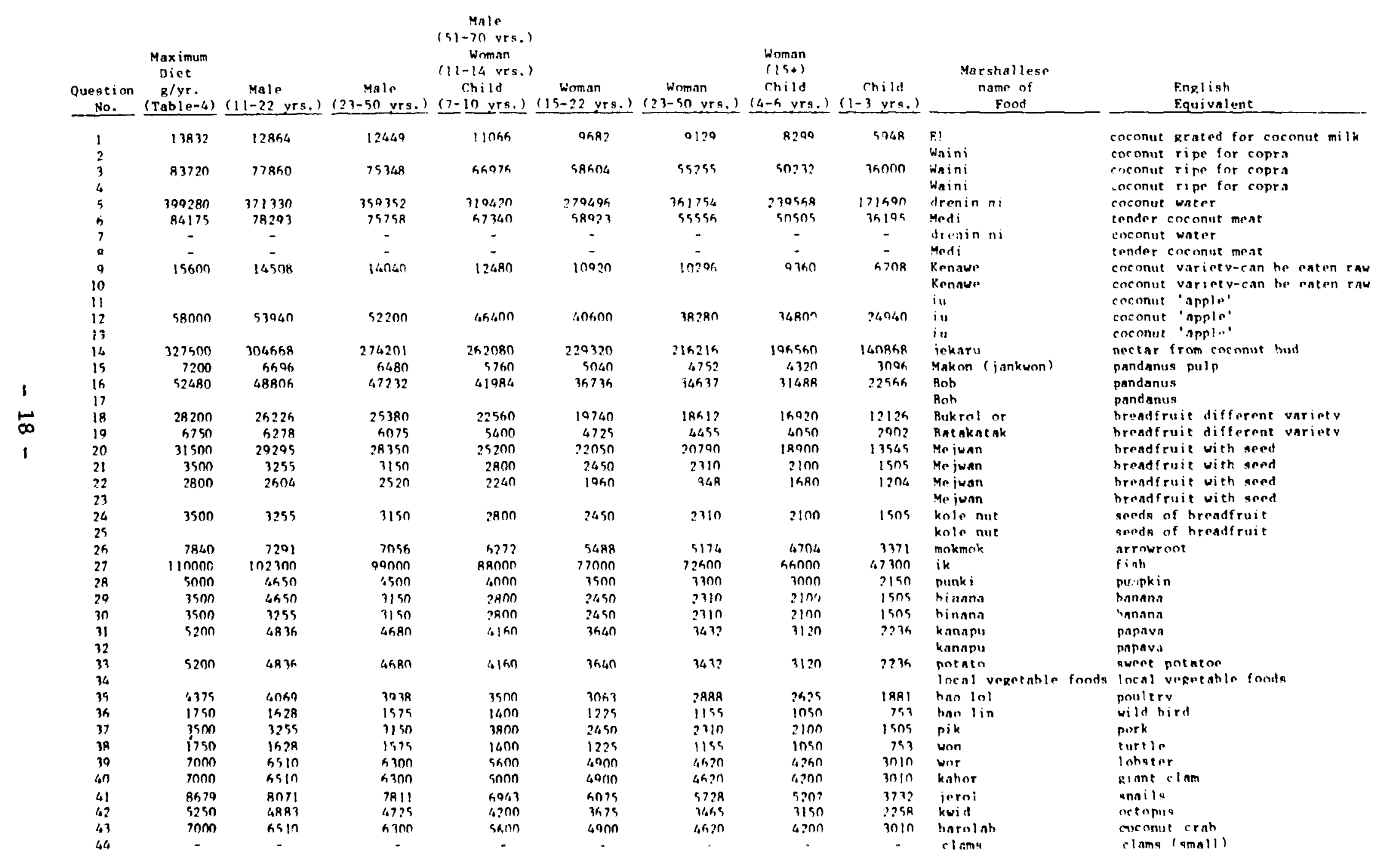




\section{List of Local Foods and Conversion Factors}

1) Coconut milk - el - One nut produces 38 grams of milk at $2.6 \mathrm{cal} / \mathrm{g} .^{2}$ A solution produced by squeezing freshly grated coconut. Often water is mixed with the coconut gratings to enhance the extraction process. Coconut milk can be used to enrich all traditional dishes and is normally mixed into food before cooking. EL is produced from waini (the mature nut).

2) Coconut meat - waini - one nut $=240 \mathrm{grams}^{3}$ at $3.1 \mathrm{cal} / \mathrm{g} .4$ (12 months stage). Often grated and mixed into food but more often eaten as a side dish with breadfruit or fish.

3) Coconut water - dren in ni $-230 \mathrm{grams} / \mathrm{nut}$ at $.109 \mathrm{cal} / \mathrm{gram} .5$ The water of the immature coconut at its 7 to 9 month stage is consumed by islanders of all ages regularly when avaiiable. The ni must be cut from the tree as opposed to waini which falls by itself. Certain varieties of ni are preferred among others for regular drinking, some varieties being seldom or never consumed.

4) Coconut Flesh - medi - $130 \mathrm{grams} / \mathrm{nut}$ at $1 \mathrm{cal} / \mathrm{gram} .^{6}$ Medi is the soft flesh which forms inside the shell of the $\mathrm{ni}$ stage. It is seldom used in cooking and eaten primarily as an in between meal snack.

5) Kenawe - 100 grams/nut at .109 caligram. Kenawe comes from a particular variety of coconut palm of which the immature, 3 to 5 month stage fruits are sweet to the taste and edible. The shell is soft at this stage and eaten like raw cabbage. The husk in its upper portion at the eye is also edible. The lower portions of the husk are chewed and the juice sucked and then these portions are discarded. Both gram weight and calorie content listed above are estimates as no data on kenawe have been published.

6) Sprouted embryo - iu - 100 grams/nut at $.78 \mathrm{cal} / \mathrm{gram} .7$ The embryo begins to form around the $15 \mathrm{th}$ month of the waini stage, and normally takes two to three months to sprout. When the sprouted nuts are used in copra making the iu is first removed before the nut is set out to dry. It is often cooked in a pot with flour and coconut milk. Sometimes it is baked still within the shell. More often it is simply eaten raw mixed with sugar water or jekaru as a meal or plain as a snack.

7) Jekan -.45 cal/grams. 8 Jekaru is the sap of the tree tapped from the flower while still at the bud (4 week) stage. Up to one gallon of Jekaru can be produced from one tree per day. Jekaru is used as a sweetener in cooking and it is drunk by children and adults fresh in a solution of $50 \%$ water. Fermentation begins immediately. It is often boiled and given to babies as a substitute of mother's milk. Unless the fermentation process is arrested it turns into a wine by about 36 hours. Fresh jekaru is often boiled into a syrup called Jekami.

8) Pandanus (preserved) - Jankwon - $9.93 \mathrm{cal} / \mathrm{gr} \mathrm{rm} .{ }^{9}$ Jankwon is produced by mashing the cooked pandanus keys into mokon, straining out the fibers which were loosened from the cores in the process, baking the resulting mash into 
a deep brown paste like substance and drying this under the sun untii it is dehudrated to the point where preservation is possible. It is then wrapped in dry pandanus leaves and tied into a neat roll until needed.

9) Pandanus keys - boh. There are two basic types pf pandanus. One is used to mash into mokon and averages about 50 grams per key; ${ }^{10}$ another type is seltom cooked, contains little pulp and only about 30 grams of juice. This latter tvpe is tupically eaten raw by chewing and sucking and then discarding the inedible core. There are about 40 keys to a stalk. No known reliable calorie comparison factors for this latter type of pandanus kev exist so we have used .58 calories/g. 11 for both types has been assumed even though this is an overestimation for the latter. Depending on location ( $i s$ land/atoll) pandanus is eaten consistently for 4 months. 12

10) Breadfruit - batakatak, bukrol. These are the seedless varieties of breadfruit. They contain about 500 grams of cooked edible portion at 1.3 cal/gram. ${ }^{13}$ Three types of breadfruit are eaten consistently over a period of about 12 weeks per vear. 14

11) Preserved breadfruit (batakatak and bukrol) - buido - 1.3 cal/gram with one fruit equal to 500 processed grams of buido. 15 The breadfruit is picked in large numbers at the peak of season, skinner, and decored, sliced and soaked within a copra sack in the lagoon for a period of hours or days. The sliced fruits are then mashed and allowed to sit and ferment underground within breadfruit leaves where drainage can take place. Before eating it is often rinsed in fresh water to reduce the salt content.

12) Breadfruit (variety with seeds) - Mejwan - 272 grams/fruit at 1.12 calories/gram, cooked and 1.22 calories/gram eaten raw. ${ }^{16}$ Mejwan is always cooked in its unripe stage though unlike other varieties of breadfruit when ripe it can be eaten raw. It can also be prepared into Jankwon by baking the ripe fruits and then drying them under the sun. The jankwon so produced contains about 2.83 calories/gram. 17 Mejwan is eaten consistently for about 9 weeks/yr. in its unripe stages and for about 5 weeks/yr.

13) Breadfruit seeds (from me iwan) - Kole - each nut weighs about 2.5 grams and contains about $1.5 \mathrm{cal} /$ gram. $^{\text {to }}$ The nuts must be cooked to be eaten, and can he considered as a significant portion of the diet for only about 5 weeks per vear.

14) Arrowroot - Mokmok - 3.5 calories/gram. ${ }^{20}$ The tubers are dug up in the winter months when the plant itself dies. They are dumped into a copra sack and rinsed of dirt in the lagoon. They are then grated into pulp which is mixed with salt water and strained to separate the starch out of the solution. The solution containing the starchy material is usually trapped in a canvas lined pit which permits the salt water to seep through the canvas into the sand leaving the chalky starch behind which resembles plaster of Paris. The starch is then wrapped in a towel and hung up to drain and dry. It can then be used in cooking without further processing. 
Footnotes for List of Local Foods and Conversion Factors.

1. Murai, Mary. Some Tropical South Pacific Island Foods, University of Hawaii Press, Honolulu, Hawaii, 1958;118.

2. Ibid 118

3. Ibid 52-7. (Murai documents the average weight of the mature coconut at 350 grams. However, as most of the coconut eaten is grated and as only $2 / 3$ of this amount is actually extracted from the she11, we have reduced Murai's figure by $1 / 3$ to 240 grams/nut.)

4. Ibid $52-7$

5. Ibid $52-4$

6. Ibid $52-4$

7. Ibid $52-8$

8. Ibid 58

9. Ibid 76

10. Ibid $67-82$

(Murai documents the average edible portion of a pandanus key at 75 grams. There are many dozens of variety of pandanus eaten in the Marshall Islands, however, though the two varieties used in Murai's study happen to be the largest. We feel $50 \mathrm{grams} / \mathrm{key}$ for the variety which produces mokon and 30 grams/key for the other type to be more accurate overall average.)

11. Ibid 58

12. See page $(5 \& 6)$ of Dietary Interview.

13. Murai, Mary. Some Tropical South Pacific Island Foods, University of Hawaii Press, Honolulu, Hawai, 1958;24-30.

14. See page $(5 \& 6)$ of Dietary Interview.

15. Murai, Mary. Some Tropical South Pacific Island Foods, University of Hawai i Press, Honolulu, Hawai i, 1958;24-30.

16. Ibid $24-30$

17. Ibid $24-30$

18. See page $(5 \& 6)$ of Dietary Interview.

19. Murai, Some South Pacific Island Foods, University of Hawaii Press, Honolulu, Hawai, $195 \overline{8 ; 3} \overline{4}$.

20. Ibid 104 . 


\section{Living Pattern Study:}

The living patterns among the Marshall Islanders vary somewhat from atoll to atoll. However, due to the consistency of an atoll environment and its $1 \mathrm{im}-$ ited land area, as well as the limitations it presents to economic development, reliable estimates can be produced if based on the average amount of time spent at the various tasks necessary for subsistence. Tables 6, 7, 8 list the time spent in various activities by males (ages 15-50 years), females (ages 15-50 years) and children (ages 6-14 years).

From information provided by the Tobolar Copra Plant which keeps copra production works for the various atolls in the Marshalls, it has been determined that the islanders of Utirik Atoll produced about 113 short tons of copra between the Fall of 1957 to the Fall of 1978. Thus this averages to about 90 lbs./week per person. This copra production represents the output of 48 males from ages 14 to 95. As all of these individuals are not involved in copra production to the same extent, it is estimated that those actually working produced

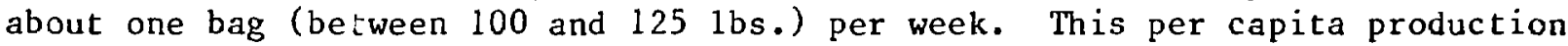
at Rongelap seemed to be considerably less, while at Ailuk it proved somewhat more. At any rate copra production - the main island commercial activity - could not possibly exceed that possible during the hours taken for coconut collecting and husking per week which we have used as the basis for island activities estimates. It has been estimated that plantation clearing (for undergrowth) adds another 4 hours per individual per week to inland activities associated with copra production. In addition to copra production, another two hours per day of inland activity has been estimated for food gathering.

This is not to say that some individuals do not spend considerably more than 26 hours/week inland. The apparent range over the entire male population is very broad, with some individuals spending in excess of 40 hours and others as 1 ittle as 7 or less.

The living patterns of women on the other hand, are noteworthy in the relative lack of inland activity. Some of the younger women are involved in coconut gathering, and, to a limited extent, food gathering. Some of the elderly women are engaged in activities related to handicraft production, (such as gathering of pandanus leaves).

Female activities on the lagoon, at the shoreline and on other small islands of the atoll appear to be an insignificant portion of their living patterns. An exception to this is found only when actual settlement of a small island for copra making purposes takes place. In general, women do not go along on the two to three day trips which the men periodically make for cleaning up of the cocorut plantation area.

In respect to male activities in the area of ship repair, a direct relationship was apparent between the number and state of repair of traditional canoes and other vessels and the amount of $t$ ime spent on the lagoon and at other islands. 
Shore time activities for men are primarily limited to fishing with throw nets, long nets and cane poles.

On the other hand children spend long hours playing on the beach and in the sand. It was estimated that as a minimum, they occupy this area during two hours of daily activity.

From the above discussion it can be seen that by far the largest amount of time in the living pattern of the islanders is spent within the village area. During the largest proportion of it ( 45 to 49 hours), they are involved in child raising, handicraft fabrication and relaxation. Indeed it is a rare instance when one stops at an islander's house to find no one there. Such situations occur only during major celebrations or during the arrival of a trading vessel.

To understand the leisurely pace of life on the outer atolls of the Marshalls, it is perhaps best to pay attention to the subsistence activities, and the life and culture supporting functions which are based upon the coconut palm. The palm has been said to be the mother of Pacific man and truly it is the pillar upon which island life revolves. From the preceding section on diet, it is apparent that by the islanders own estimate, the coconut palm provides from 48 to 58 percent of the food for the traditional as we 11 as the contemporary local diet. Fish, which can also be gathered quickly and in great abundance constitute the second major portion of the diet and the other main support for island 1 ife and culture. Together these two items provide from 78 to 84 percent of the local food diet. It is upon the availability of these staples, which the environment provides abundantly, that atoll life, as we know it today was established. Even though many of the subsistence skills which enabled the ancestors of the present islanders to thrive and establish their once selfreliant culture have been lost, and though the islanders can in no sense be considered or expected to be totally self-sufficient in terms of their diet, the local food resource foster and support this leisurely pace of 1 ife. They can be expected to turn to it in lean times, when for one reason or another the much preferred rice, sugar and flour imports become scarce or unattainable. 
A. Inland activities - (26 hrs./week)

hrs./week

1. Brushing plantation

4

2. Coconut collecting

4

3. Coconut husking

4

4. Food gathering of pandanus, breadfruit, ni, iu, Jekaru

$\operatorname{tota1}(A) \quad \frac{14}{26}$

B. Activities on lagoon (9 hrs./week)

1. Fishing on lagoon

7

2. Inter atoll travel (0-2 hrs.:

total (B) $\quad \frac{2}{9}$

C. Activities at shoreline ( $7 \mathrm{hrs}$. $/$ week)

1. Fishing at shoreline

total (C)

7

D. Activities on other island (2 hrs./week) total (D)

$\underline{2}(0-2$ hrs. $)$

E. Activities in Village area (124 hrs./week)

1. Canoe and net making and repair

2. Clean up of living area 7

3. Coconut cutting and drying 4

4. Church activities, meetings, celebrations 8

5. Sleeping 56 
Table 6: Male Activities (Cont'd)

(15-50)

6. Child rearing (and monitoring), handicraft,

hrs./week relaxation

45

total (E) 124

Total (A-E) 168 
A. Inland activities ( $8 \mathrm{hrs}$./week)

hrs./week

1. Coconut gathering and splitting, gathering total (A) $\mathbb{8}$ pandanus leaf

B. Activities on lagoon (none)

$\operatorname{total}(\mathrm{B}) \quad \mathrm{nil}$

C. Activities at shoreline (insignificant) total (c) insignificant

D. Activities on other islands (insignificant) total (D) insignificant

E. Activities in village area

1. Preparation of food 28

2. Splitting coconut shells and drying 4

3. Clean up of living area 7

4. Washing clothes 8

5. Church activities, meetings and celebrations 16

6. Sleeping 56

7. Child rearing, handicraft, relaxations 49

$\begin{array}{rr}\text { total (E) } & 160 \\ \text { Total (A-E) } & 168\end{array}$


A. Inland Activities

hrs. / week

1. Collecting iu, gathering coconuts

tota1 (A)

10

B. Activities on lagoon

1. Inter Atoll travel (0-2 hrs.)

total (B)

2

C. Activities at shoreline

1. Play

total (C)

10

D. Activities on other islands (0-2 hrs.)

total (D)

2

E. Activities in village area

1. School

2. Clean up of living area

3. Washing clothes or drying copra or household chores, etc.

4. Sleeping

5. Play and relaxation 


\section{References:}

1. Murai, Mary (1954). Nutrition Study in Micronesia. Atoll Research Bullet in \#27. Pacific Science Board, NAS - NRC. Washington, D.C.

2. Murai, Mary, F. Pen, and C.D. Miller (1958). Some Tropical South Pacific Island Foods. University of Hawai Press, Honolulu.

3. Persona1 Communication Notes:

a. E.E. Held, University of Washington (May 1958)

b. R.A. Conard, Brookhaven National Laboratory

4. Chakravarti, D., and E.E. Held (1961). Chemical and Radiochemical Composition of the Rongelapese Diet, Report 非UFL-77, University of Washington, Seattle, Washington.

5. Robinson, W.L., W.A. Phillips and C.S. Colsher (1977). Dose Assessment at Bikini Ato11. Report \#UCRL-51879 Pt. 5. Lawrence Livermore Laboratory, Livermore, California.

6. USAEC (1973). Enewetak Radiological Survey. Report 非No-140 Volume 1. Nevada Operations Office, Las Vegas, Nevada. 


\section{Appendices}

A. Seasons: i. Local foods

ii. Seasons of the year

B. Marshallese (local) foods

C. Other Islands used for food gathering

D. Data on edible portions of Marshallese foods

E. Fishes: Types of fishes and methods of fishing

F. School children - lunch program

G. Typhoon relief

H. Food supply ships - trip reports

I. Private or community stores - types of foods available 


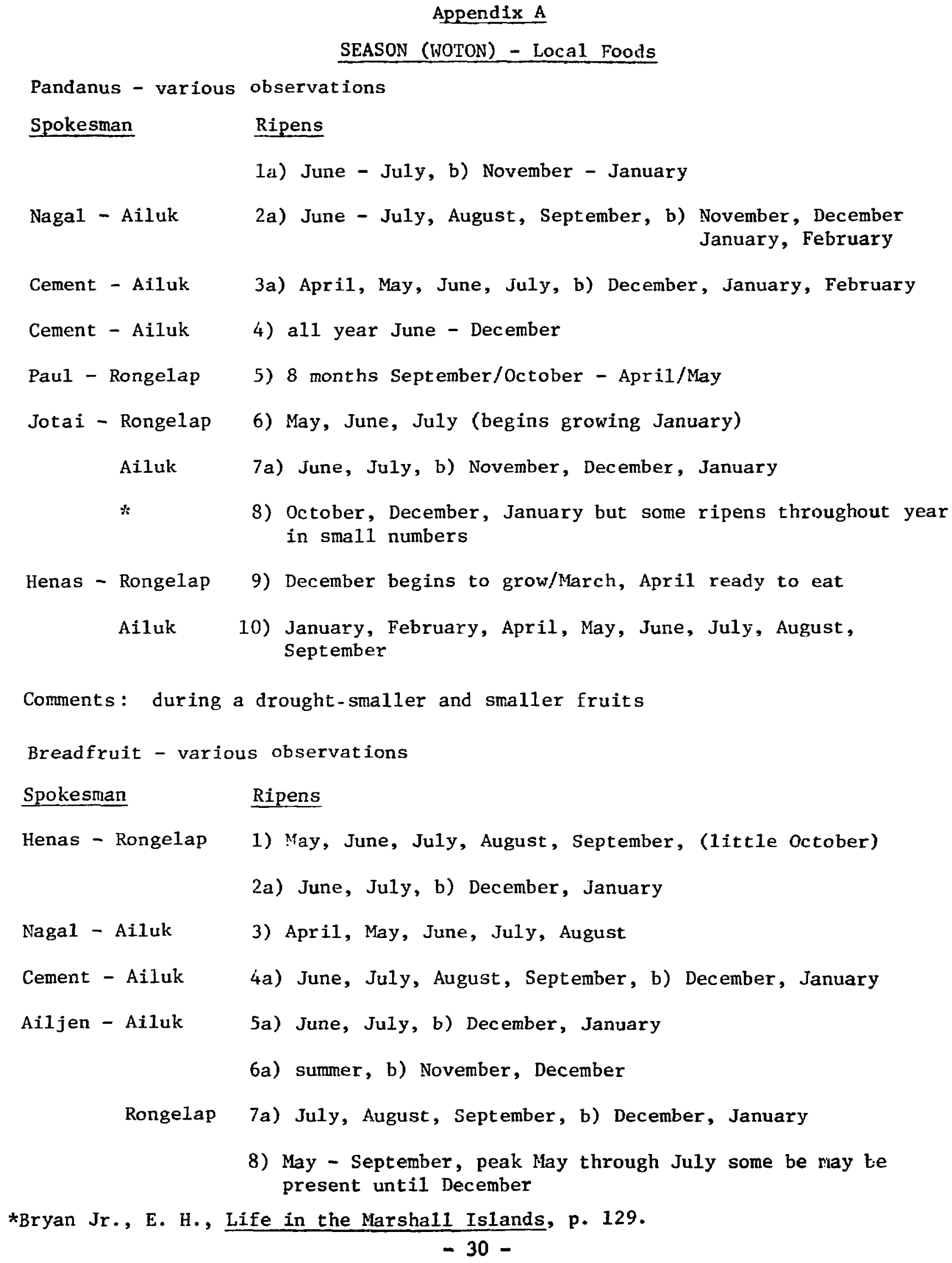




\section{SEASON (WONTON) (cont'd)}

9) December, January, February, April, May, June, July (mokan)

Comments: After a breadfruit season, pandanus follows. They alternate seasons. (Nagat - Ailuk)

Bananas - various observations

Spokesman

Nagal - Ailuk all year around

Hemos - Rongelap all year - more in rainy season

Arrowroot

Spokesman

Hemos - Rongelap November, begins growing, December and January ready to eat

Nagal - Ailuk December, January, February

October through January

Rongelap January, February, March, April

Coconut - iu (flowering coconut)

Spokesman

Nagal - Ailuk whenever anybody wants to find and eat it

Pumpkin

Spokesman

Nagal - Ailuk all year

Cement - Ailuk all year

Sue - Rongelap all year

$I$ month for pumpkin to become large

*Bryan Jr., E. H., Life in the Marshall Islands, p. 129. 


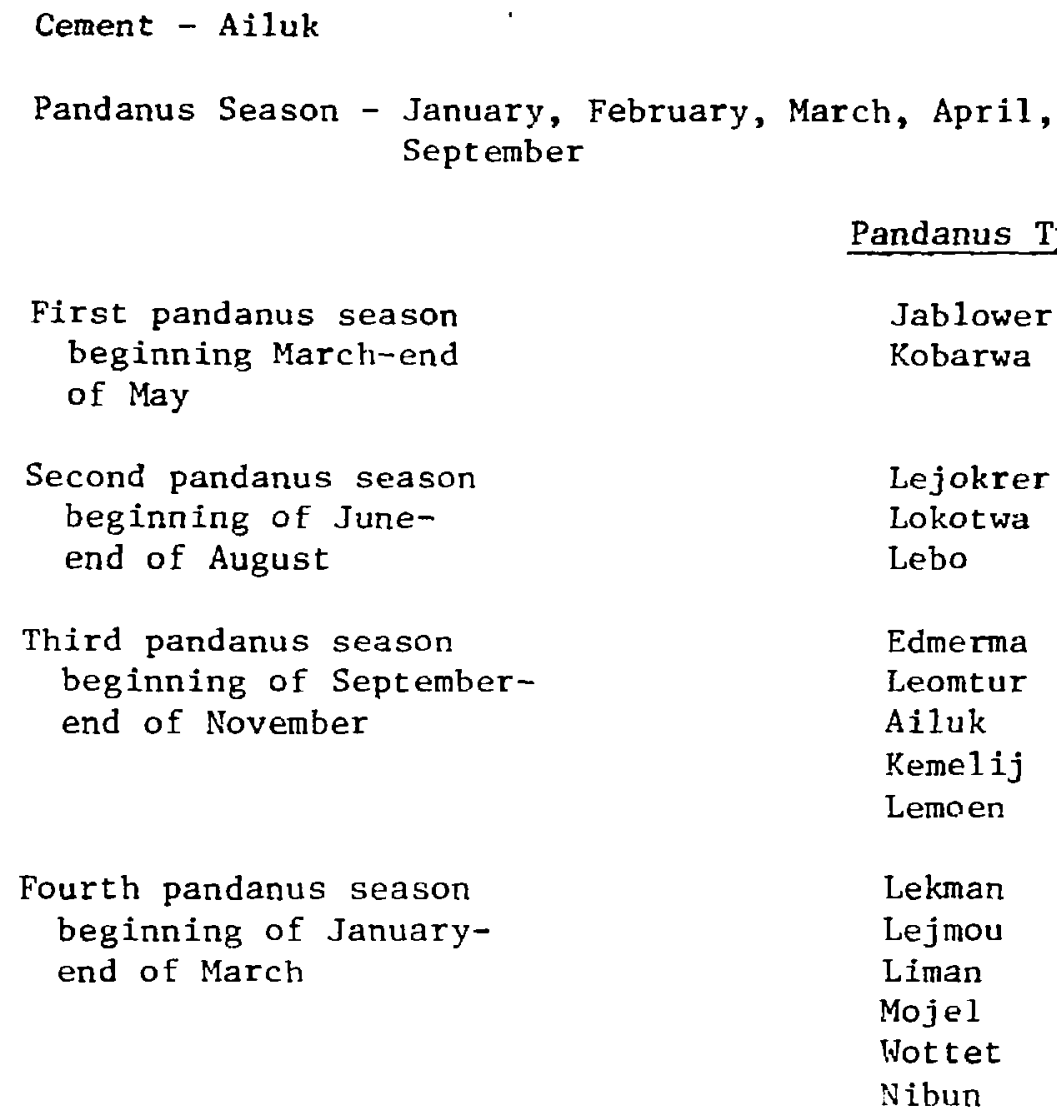
Sept ember

First pandanus season beginning March-end of May

Second pandanus season beginning of Juneend of August

Third pandanus season beginning of Septemberend of November

Fourth pandanus season beginning of Januaryend of March

Jablower

Kobarwa

\section{Lejokrer \\ Lokotwa \\ Lebo}

\section{Edmerma \\ Leomtur \\ Ailuk \\ Kemelij \\ Lemoen}

Lekman

Lejmou

Liman

Mojel

Wot tet

Nibun

Pandanus Types

The information given by the Marshallese seems to show two seasons for both breadfruit and pandanus. This is a widely accepted fact and tends to support our own observations made during our extended stay on the islands in the Marshalls. According to the above figures, one would expest that the summer season, which bears the largest crop and is the time when preserving is normally done, begins around the second week of May and continues progressively until July--the month when the preserving is traditionally done and continues on into the second or third week of August. The second or winter breadfruit crop falls in December and January.

It should be noted that the pandanus season is markedly different in the Northern Marshalls where due to lack of rain in the winter months, the summer crop is normally much larger. To some extent, this holds true for breadfruit as wel1--the winter crop being much smaller. 
SFAS'XS (WONTO: (cont'd)

Taro

Spokesman

Nagal - Ailuk grows all year

OBSERVATIOXS ON SEASONS OF YEAR

Summer season of maximum rainfall in the year*

rainy season on Ailuk May, June, July, August; rlows down September, October, Novenber, December

Rainfall

decreases as you go north

average rainfall: Jaluit - 160" Wake Island 30 to $50^{\prime \prime}$

(350 miles further north)

Majuro - $120^{\prime \prime}$

l'jelang - 80"

Eniwetak - 60 to $70^{\prime \prime *}$

Winter

December - April, season of strong winds from the northeast. Dry period of the year.*

Temperature ${ }^{\circ} \mathrm{F}$

range varies less than $10-12^{\circ} *$

Minimum: $69^{\circ}$

Maximum: $80^{\circ}$

*Bryant Jr., E. H., Life in the Marshall Islands, p. 135-36. 


\section{Append ix B}

\section{Marshallese Foods}

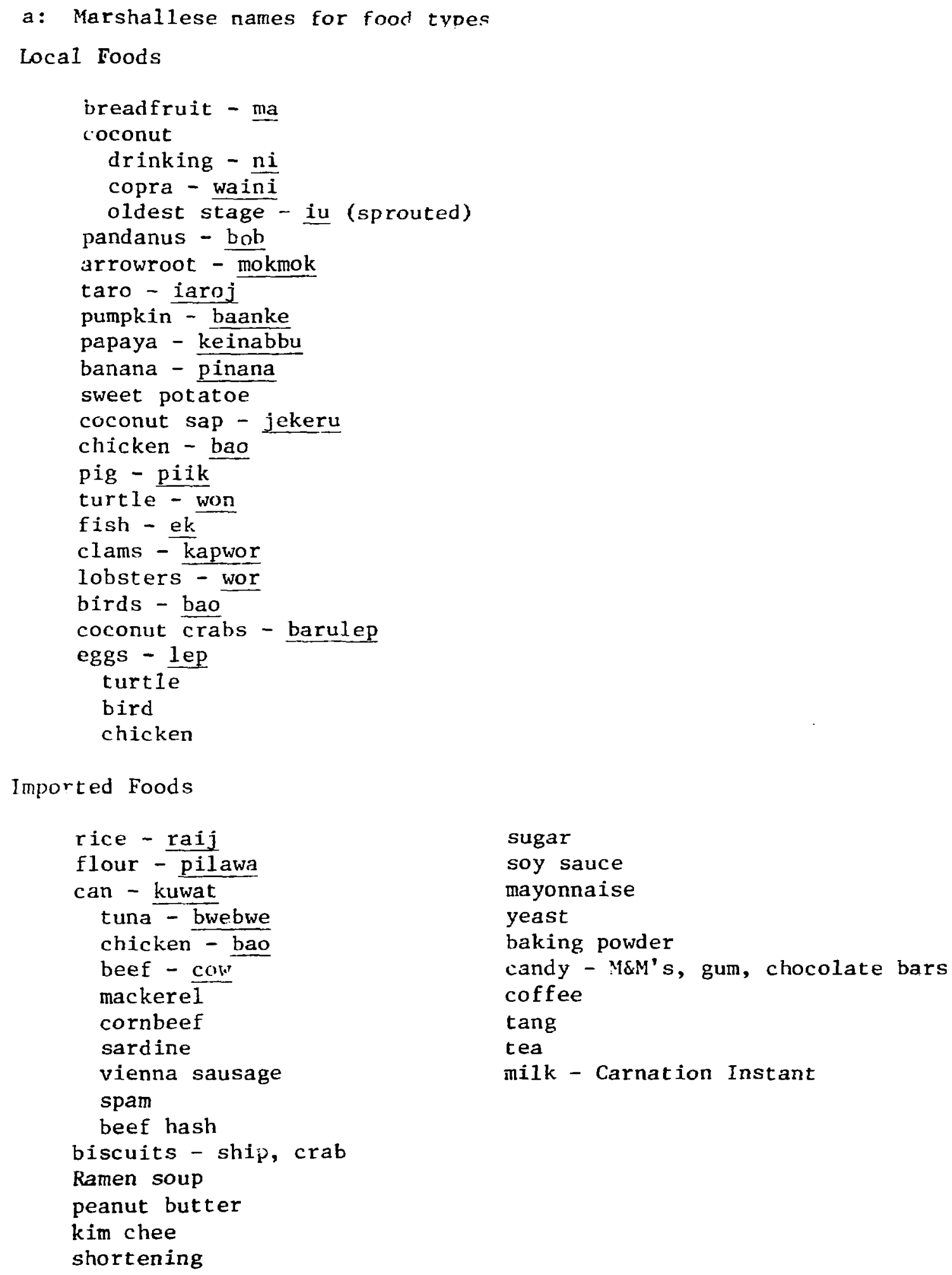




\section{b: Cooking Modes}

(1) Ground oven - UM - The ground pit is fueled by a coconut shell or husk fire. Rocks are tiien added to cover the coals. When the rocks have been warmed the food is placed in. The pit is covered over with banana leaves, canvas or a heavy rubber sheet. Weights are added.

(2) Stove Type Cooking - is älways done either over a kerosene stove or an open fire fueled by coconut shells or husks.

a) boiling - using rainwater, brackish water when rainwater supply is low.

b) frying - using Crisco, other shortenings, occasionally pig grease, rarely if, ever coconut oil.

c) steamed -

(3) Roasting - is done over a coconut shell or husk fueled fire, when it has turned to coals.

$$
\begin{aligned}
& \text { c: Description of the Food Types } \\
& \text { 1. Breadfruit - MA }
\end{aligned}
$$

(1) Kwanjin - green breadfruit roasted on coals until skin is black. The outside is then scraped with pieces of broken glass or shell. Approximately $1 \frac{1}{2}$ hours to cook.

(2) Steamed - fill the iron pot with water up to metal disk. Cooking time varies according to type being cooked.

a) bwiro - 2 hours to steam on fire

b) raw breadfruit (whole) 30 minutes by stove

(3) Boiled - wash green breadfruit leave whole and boil.

(4) Kopjar - baked breadfruit in ground oven.

(5) Jokkwapin Ma - Breadfruit soup is made by removing the core and skin, cutting the rest into pieces which are boiled, mashed, mixed with coconut milk and salted to taste.

(6) Fried - Cut the ripe breadfruit into slices removing the outer green peel. Soak the wedges in salt water or salt them before frying. Cooking time approximately 10 minutes on each side until brown or french fried.

(7) Kalo - very ripe breadfruit mixed with coconut milk.

(8) Mijiwan - a type of breadfruit which is eaten raw when it is very ripe; as is or with coconut milk.

(9) Kwolejiped - name of nuts (kwole) cooked. They are roasted on coals or taken out of a steamed, baked, or builed Mijiwan Breadfruit. 
(10) Bwiro - preserved breadfruit or Marshallese cheese. The skin is removed from the ripe green breadfruits then cut in wedges and placed in a burlap bag and taken to the lagoon. The bag is anchored for one or two days in the saltwater or stomped on for an hour or so to hasten the fermentation. The bag is then taken from the water and left on coconut leaves in the open air for one or two days. The breadfruit is then placed in a pit lined with breadfruit leaves. Leaves, a cloth cover and weights are then placed over the breadfruit. The breadfruit leaves are changed after every month and the bwiro is ready for cooking after two months. Supply can be kept six months to a year or two. (Type of breadfruit used--bakrol, batatak, koutroro.)

Bwiro Food Preparation

The quantity of preserved breadfruit that is needed to cook with is taken from the pit or box and thoroughly washed in fresh water Coconut milk is then mixed with the rainwater. Sugar is also added along with flour which is optional. A ladle full of the mixture is then placed in a breadfruit leaf and is either. steamed, boiled, or baked. Another method of cooking is to roll the bwiro into balls and then steam or boil.

(11) Baked - The inside stem of a ripe breadfruit is removed and coconut milk replaces it. The breadfruit is then wrapped in leaves and baked.

(12) Jankwin - Mijiwan seeded breadfruit is picked green; allowed to ripen; seeds, core and skin removed; placed in a coconut leaf basket; baked in earth oven all night; taken out; unwrapped; flattened and allowed to dry in sun. When dry, it is rolled, wrapped in pandanus leaves, tied with sennit twine and preserved as a roll. 


\section{Coconut}

The coconut was traditionally and still in some circumstances continues to be the focal point upon which the Islander's diet revolves. Indeed nothing is found in greater abundance among the atolls than coconut. The tree itself was an important foundation upon which Island life evolved. The leaves being woven into shelters and the fibrous strands of the husk twisted into sennit rope for the lashings of houses and outrigger canoes. The bud-sheath was used as a bowl in which to pour ingredients to bake in ground ovens. Baskets woven from the leaflets of the tree were, and occasionally still are, commonly used for eating and displaying and transporting food.

The coconut fruit requires approximately 12 months to ripen and usually falls off itself after an additional few months due to stem decay. At this stage it is ready to be husked, broken open and dried under the sun or in a smoke-house into copra, the major island export. And at this stage it can be opened and the nut cut from the shell and eaten as jiral (with something else) fish, for instance or breadfruit or both. It has a high oil content however and a two to four ounce portion is seldom exceeded unless there is a scarcity of imported or other local foods. Children seem to eat considerably more of it than adults do. The elderly, on the other hand, especially those lacking teeth, eat it normally only when it is mixed into the family food. Binbin is a term that is used to describe the preparation of a variety of dishes in which mashed banana or tarro or breadfruit or more likely rice, is formed by hand into a ball and rolled over coconut gratings which stick to the surface and help preserve its shape. These gratings are produced in a process called ranke whereby the nut is scraped from its shell by a rounded, tooth edged blade normally screwed onto a stool on which one can sit while engaged at the grating or ranke process.

The water of the mature coconut or waini is sometimes drunk. More often, however, it is mixed with food as an ingredient before cooking or not being as sweet or flavorful as the water in the unripe nuts discarded altogether. The earliest stage at which the water begins to sweeten and is used for drinking is termed obleb--around its sixth month of growth. The shell is still soft enough to break with the fingers and the nut itself--if it has started to form at all--is but a thin gelatin lining the bottom of the shell that can be loosened with a thumbnail and drunk. The next stage when the gelatin hardens as does the shell allowing itself to be husked is called ni. This is the stage at seven to nine months when the nut is normally used for drinking. During this period, the nut continues to form though its texture remains soft and removable from the shell by the thumbnail. When it becomes too hard for this and begins to become cemented to its shell at around nine to ten months, it is called mejob. The meat of the nut is hard though not quite as hard as in he mature, waini, stage and not as oily. Mejob is seldom eaten today though it was in the past and may one day again be a staple to ward off hunger in times of famine. This is due to its abundance and to the fact that the lower oil content allows for a larger quantity to be eaten before bringing distress to the bowe1. It can be grated by the ranke process and is sometimes used in this way mixed as an ingredient into food or put in a bowl with jekaro and eaten as a sort of cereal called jekbwa.

Jekaro is a nectar collected by binding and repeatedly (morning and evening) cutting the budding composit flower of the coconut tree. As the tree produces one bud a month and as a bud can be tapped for a period of up to four months, a good 
tree can have up to four bottles containing up to a gallon of jekaro hanging and waiting to be collected each morning. The tree will produce a similar quantity that must be collected in the evening. It is very sweet and is usually mixed with water for drinking and very nutritious, especially after four to six hours at which point the yeast content is greatest. After this it begins to become noticeably alcoholic and at 36 hours when the fermentation process stops, it can be drunk as a wine. In its sweet, unfermented stage it has been used as a substitute for mother's milk. When available, it can be used as a sweetener in any or all of the traditional dishes. When it is boiled down, it yields on an eight to one ratio a delicious syrup termed jekami which is used as a sweetener in drinking and also eaten with coconut at its various stages. It can be mixed and further cooked with coconut gratings to produce a type of coconut candy, much prized, called amitama.

At around the 15 th to 18 th month, the coconut begins to sprout. At this time, the inside of the nut turns gradually to a sweet apple-like, spongy substance called iou. A side product in copra making, it is eaten in the interior islands by those gathering the nuts. Then again eaten by those while husking. When the nuts are cracked, children flock to the area to scoop out the soft iou before the nuts are layed out under the sun. Iou is sometimes crushed and mixed raw with jekaro and thickened with flour into a pudding--aikiou. Also it can be steamed or baked in a basket (iutur) or even while still in the nut (umum ilo lot).

To the aikiou dish el is often added. Indeed it is through the el or famous "coconut milk" that the coconut can be seen as the central ingredient in all traditional cooking. El is obtained by mixing the grated coconut or waini with a little water and squeezing. Much of the oil and a sreat deal of flavor is thereby released into solution--pure white in color. E1 can, and often is, mixed into every dish conceivable. When available, it is normally mixed into the rice on a daily basis at the rate of about one coconut per two cups of rice. 


\section{Coconut - ni}

ni - 1 to 5 months growth

1) young drinking

method - drink through hole in husk, shell too fragile to husk, gelatinous coconut meat

2) mature drinking coconut

method - husk coconut before drinking coconut meat firm, use knife to cut from side

3) waini - 6 to 7 months growth

copra-producing coconut

use of liquid - usually thrown away, children drink occassionally

use of meat - eaten a) cut in wedges-with fish or by itself

b) grated and squeezed for coconut milk

c) use gratings in cooking, rice balls, mokan

4) iu - 8 to $81 / 2$ months growth

spongy food inside sprouted coconut

use of iu a) eaten raw

b) cut up and boiled with sugar or jekeru

c) cut up and boiled with flour, sugar or jekeru

d) raw iu cut up and sweetened with sugar or jekeru

e) iuwumum - spongy meat of sprouted coconut baked in its shell

f) iutir - baked spongy meat

Food from coconut sap

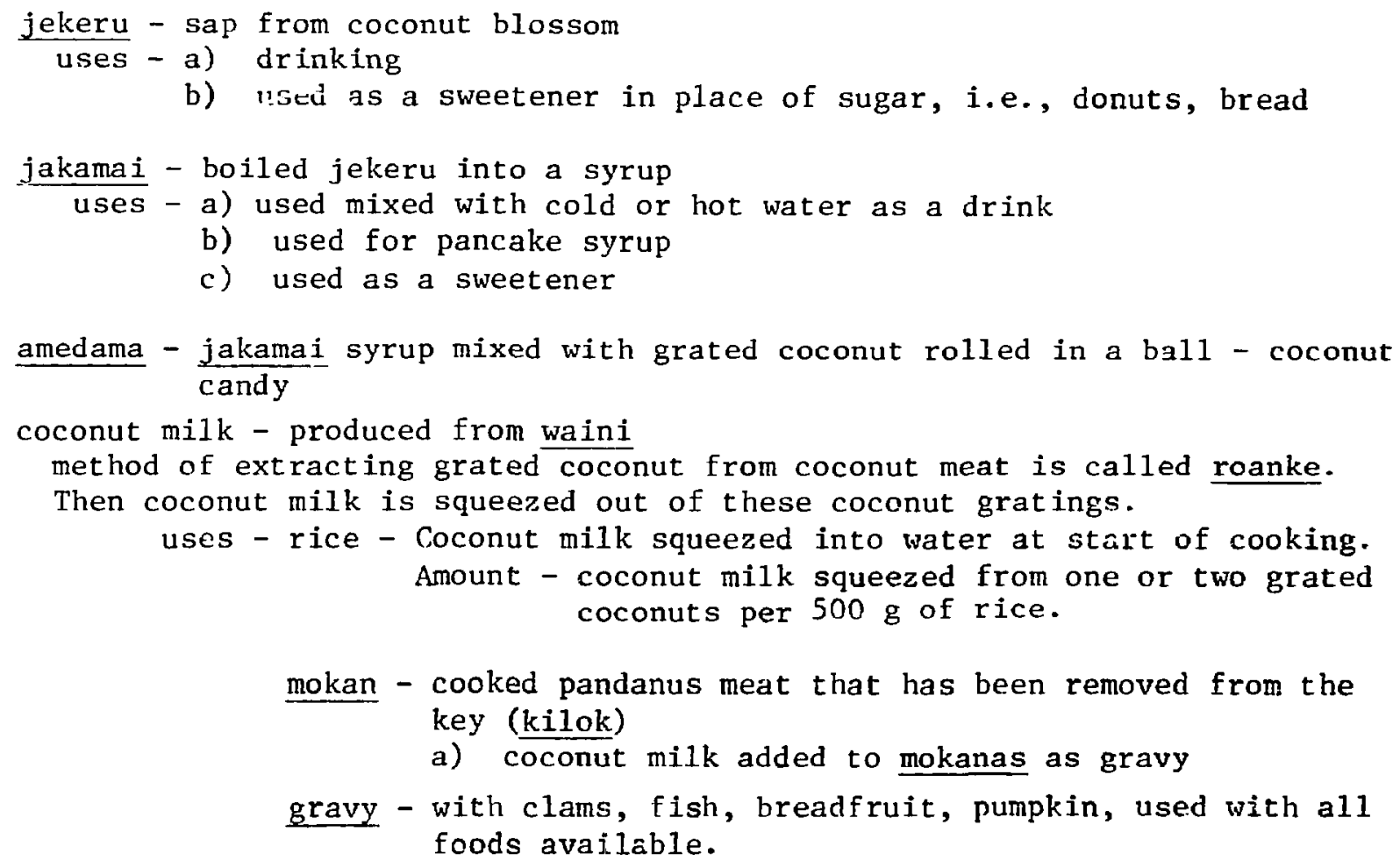




\section{Pandanus}

The Pandanus fruit resembles a huge pineapple at superficial external glance. However, a closer inspection shows it to be made of large, individually extractable kernels surrounding a central inedible core, much like corn does on its cob. A pandanus fruit can weigh up to thirty pounds and cor-ist of up to forty kernels or keys. These keys themselves are stringently fibrous in nature (indeed, a spent and dried key makes an excellent paintbrush), the inner portion of which contains the flavorful though somewhat stringy pulp which when raw has the consistency of a carrot and likewise can be mashed upon being cooked. The bulk of the pandanus fruit and a considerable portion of its weight is attributed to the upper inedible partially external portion or the keys. This external portion, which is particularly fibrous, is capped by a tough and nobby rind.

Pandanus is traditionally a very important staple for the Marshall Islanders, especially among the northern atolls where due to lack of sufficient rainfall depend less on Breadfruit, tarro, bananas and papayas then do those Islanders living in the southern Marshalls. All over the islands it is eaten when ripe uncooked and in sufficient quantity to be considered a staple. Because of its availability throughout the interior or most islands and because it grows on even the distant unpopulated islands on all atolls, it is often used to ward off hunger during copra harvesting, brushing, fishing and inter-atoll travel. It is considered to offer relief from "morning sickness" and is sought by pregnant women who often eat tremendous quantities of it. Said to be good for sea-sickness it is piled onto vessels of all types and destinations and eaten by nearly everyone aboard during the ertire length of the trip. The fact that it can be knocked about a great deal without danger of spoilage (due to its particularly tenacious rind) makes it especially suitable for inter-atoll export where it brings a good price in the district center and on Ebeye.

There are many different varieties of pandanus, some of which are always eaten raw. Others are normally boiled, steamed or baked in a ground oven before eating or processing because they are more starchy, very difficult to chew in their raw state and much more tasty and in particular sweeter after being cooked. These later are the varieties used in the preparation of mokon--the mashed pulp once it has been separated by mechanical means from the fibrous core using an apparatus called the bakan--in the process called kilok. Cooking allows pandanus to be eaten even in its unripe stages though generally speaking the more ripe the fruit the more mokon is produced in the kilok process. The varieties of pandanus are seemingly endless. Each variety has a characteristic shape, consistency, and flavor.

Jarkwon is prepared from mokon by baking it to further seduce its water content and then by spreading it out usually on leaves to dry in tie sun. The final product is then traditionally wrapped in pandanus leaves and tied with sennit. Though jankwon production is nearly a lost art over much of the Marshalls, it is still continued among the northern atolls, including Rongelap and Utirik where it is apparently a more firmly rooted tradition. 


\section{Pandanus - bob}

fresh - eat when ripe or uncooked

eroum - boiled pandanus

bake - bake keys in ground

peru - Pandanus pulp and juice mixed with grated coconut and coconut oil and optionally with arrowroot starch, wrapped in breadfritit leaves and boiled or baked.

mokan - The pudding from a cooked pandanus key. The food is removed from the key by a process known as kilok. The cooked pulp is then mixed with other foods or eaten as is.

Examples: a) often mixed with grated coconut

b) mixed with coconut milk

c) served with fish

d) by itself as a dessert

jankwin - Cooked pandanus, extract from keys keys--mokkay, dry in sun, wrap in pandanus leaves and tie with sennit twine.

unripened pandanus - mashed with sugar or jekeru and water.

$$
\text { 4. Arrowroot - mokmok }
$$

The arrowroot is dug up from the oceanside of the island, placed in a burlap bag, and washed until white. Each separate piece is then grated with a rock. The arrowroot is placed in a wanliklik made of sennit (from fibers of coconut husk)used for straining arrowroot starch. It is then rinsed with two buckets of saltwater. The arrowroot powder is then saved from the canvas or wanliklik, wrapped in a cloth and tied in a tree to dry. The powder is then removed from the cloth (bag), dried in the sun and then stored for future use.

ways of cooking - a) boiling with waini

b) Beru Pandanus and mokmok

\section{Taro - iaraj}

Stem and leaves are cut off and the remaining roct and sugar (optional) added to boiling water. Cook one hour.

The root is also baked. 


\section{Fruit - kwale}

\section{banana - binana}

when consumed and cooking method a) eaten when ripe

b) baked, when not ripe

c) fried

d) boiled in skin

e) mashed and mixed with coconut milk and coconut syrup, when ripe

papaya - keinabbu

when consumed and cooking method a) raw

b) boiled and added to meat gravy

c) boiled

pumpkin - baanke

when consumed and cooking method a) boiled

b) cooked in gravy

c) with coconut milk

sweet potato

when consumed and cooking method a) baked

\section{Meat - kanniok}

chicken - bao

eaten: meat, liver, kidney, heart

methods: cleaned, boiled

cleaned, boiled, fried

cleaned, fried

baked (rarely)

gravy - flour, shoyu, pumpkin, ma, keinappu bop made leftover
soup rice, same fruits as above
When eaten

special occasions--birthday, Christmas, Easter, parties fish - ek

eaten: most meat on head, eyes, suck on bones

methods: not cleaned - cooked in skin on coals

fried with salt

cleaned, wrapped in coconut leaves - boiled

baked (rarely)

gravy - flour and fruits

soup - rice, fruits

cleaned, salted, dried in sun

fresh or sashmi

salted - 2 days in sun - meat good for 3 or 4 days

fry with coconut milk - stays good for months (preserves)

Note: one can eat fish for three days if it is cooked everyday 
When eaten

pig -pik special occasions--birthday, eaten: meat, fat, heart, kidney, brain, suck on bones Christmas, Easter, parites methods: fried and skin salted

gravy - flour, shoyu baked (rarely)

boiled - 20 minutes, add seasonings such as onions, garlic, vinegar, shoyu, salt if available

turtle - won

eaten: meat

methods: baked - most common method of cooking

fried - when there is grease

wild birds

eaten: meat, suck on bones

methods: cook on coals

fry if grease available

ground oven baking

clams - kapwor - killer clams

methods: boil

fry

eat with $\underline{e l}$ - coconut milk the whole island eats when a turtle is caught-no special time

mostly when overnight on other island, enroute to cther islands, or special food gathering, trip made

whenever diving for them mostly in conjunction with fishing

on fishing trips, when full moon is out and man goes to oceanside to get it.

on fishing trips, overnights

coconut crab - barulep

eaten: tail, claws

methods: cook on coals

Eggs

wild bird eggs

method: boil

chicken eggs

methods: boil

fry

used in other cooking

ground oven baking

turtle eggs

nethods: boil
Easter time and when special food gathering trips may have been made

not eaten much, reserved for production of chickens; eggs, generally thought to be for sick and pregnant people

eaten when found - usually no special trip is made to get them 


\title{
8. Rice
}

\begin{abstract}
Rice is cooked with coconut milk (el) which has been squeezed from coconut gratings. These gratings come from the copra producing coconut (amountsone or two coconuts used per 500 grams of rice.

rice jokkwop - soft rice soup--water, rice flour, sugar, coconut milk

rice balls - cooked rice rolled in balls with grated coconut on outside used on special occasions, size of tennis ball.
\end{abstract}

\section{F1our}

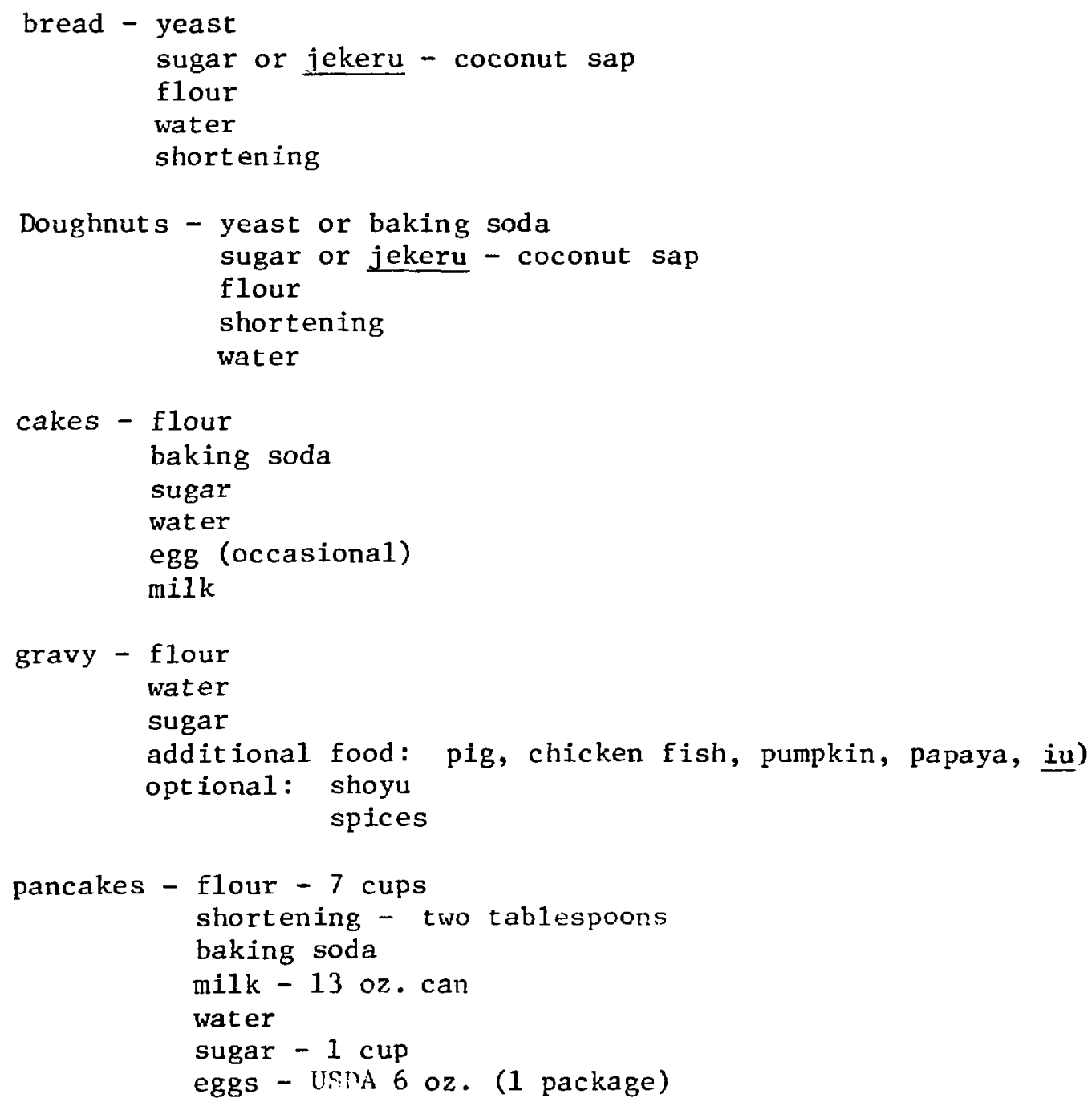


Appendix $\mathrm{C}$

Other Islands Used for Food Gathering

RONGELAP

No. of Times a

Year Frequented

Name of Island

Foods gathered and Copra

4

$2 \cdot 4$ days

24 days

12 days

12 days

12 days

6 days

6 days

6 days

6 days

6 days

6 days

4 days

4 days

Eniutok
*people are apt to
Edbot

Luwataki

Likaman

copra

*people stay over 2 weeks a year

Arbar

Keruke

Burok

Kape11e

Naen

Ailañinai

Rongerik

Malu

Jokrak

Einablar copra making it) making $i t$ ) turtle

no information birds, eggs

no information p. us, breadfruit, coconut crab, iu, fish, turtle

coconut crab, pandanus, iu, fish, lobster, turtle, coconuts, copra

pandanus, coconuts, fish, iu, turtle, coconut crab,

coconut, iu, pandanus, turtle, coconut crab, coconut crab, fish, pandanus, iu, turtle, coconuts

fish, ia, coconut crab, arrowroot, turtle, pandanus breadfruit, clam, copra

coconut crab, pandanus, breadfruit, fish, iu, turtle, coconuts, copra (but not presently

coconut crab, pandanus, breadfruit, fish, $\mathbf{I u}$, turtle, coconuts, copra (but not presently

fish (reef, lagoon), turtle, eggs, coconut crab, coconuts, copra (but not presently making it)

Birds, bird eggs, coconut, coconut crabs, ciams,

birds, birds eggs, coconut, pandanus, turtle, clams

fish, iu, turtle, coconut crab (don't normally eat),

Note: Now they have five outrigger canoes plus their community boat which they had before (often times not working). They are more mobile now and have more money to use the community boat so these figures are sure to change. 
UTERIK

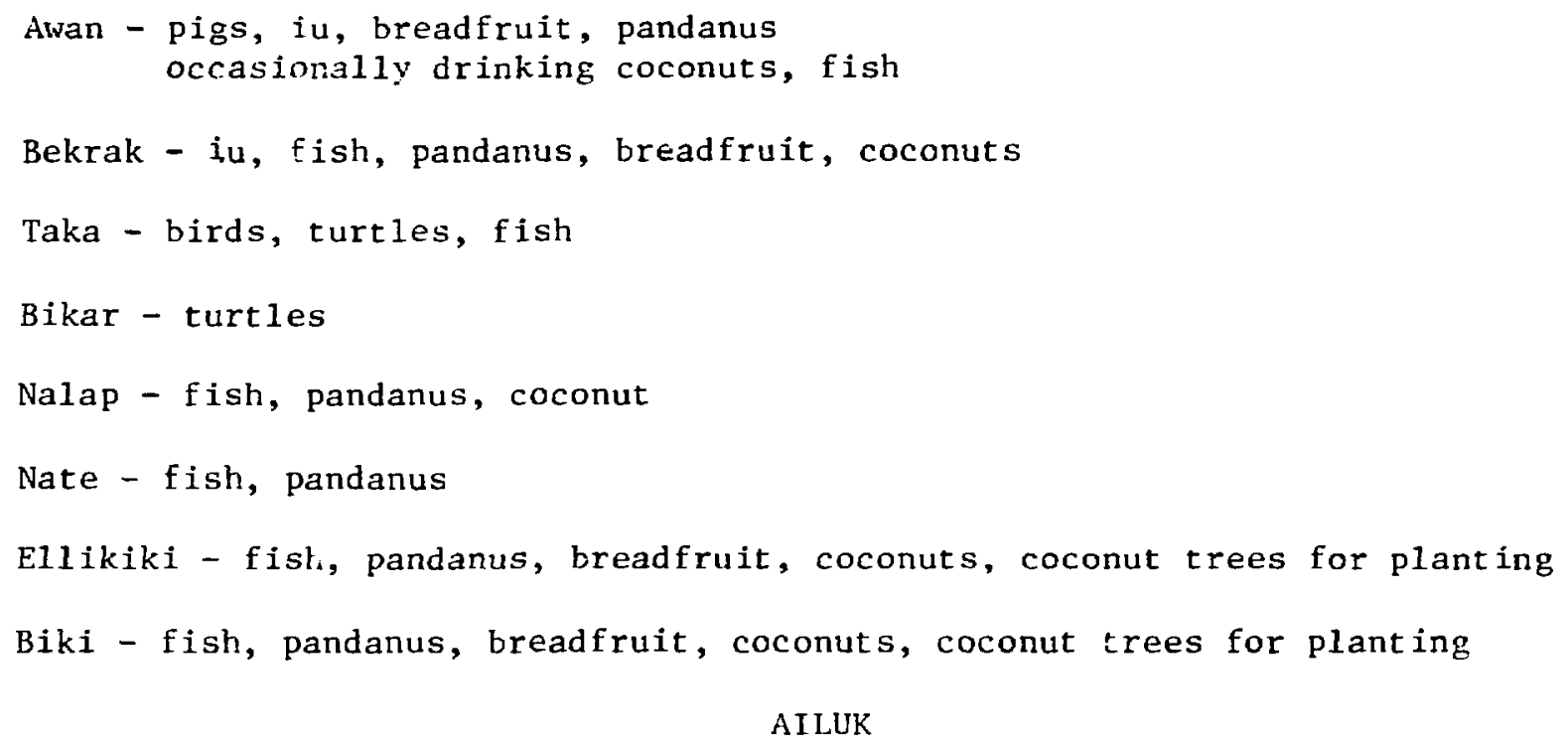

Island

Kaben
Enejabruk
Enejelar
Bikon
Ajilep
Aliej
Akulwe*

\section{Food Gathered}

breadfruit, fish pandanus

coconuts, pigs

coconut crabs

arrowroot 
WOTHO

$\left.\begin{array}{l}\text { Bigkin - birds } \\ \text { Anibling - birds }\end{array}\right\} \quad$ especially during Christmar and other special occasions

Kapen - breadfruit, pandanus

Medron - breadfruit, pandanus

Eneobinek - breadfruit, pandanus

al1 islands - coconuts, coconut crab, turtle, lobster 


\author{
Appendix !) \\ nata on Edible Portions of Marshallese Foods \\ COCONUTS - DNINKING
}

Rongelap

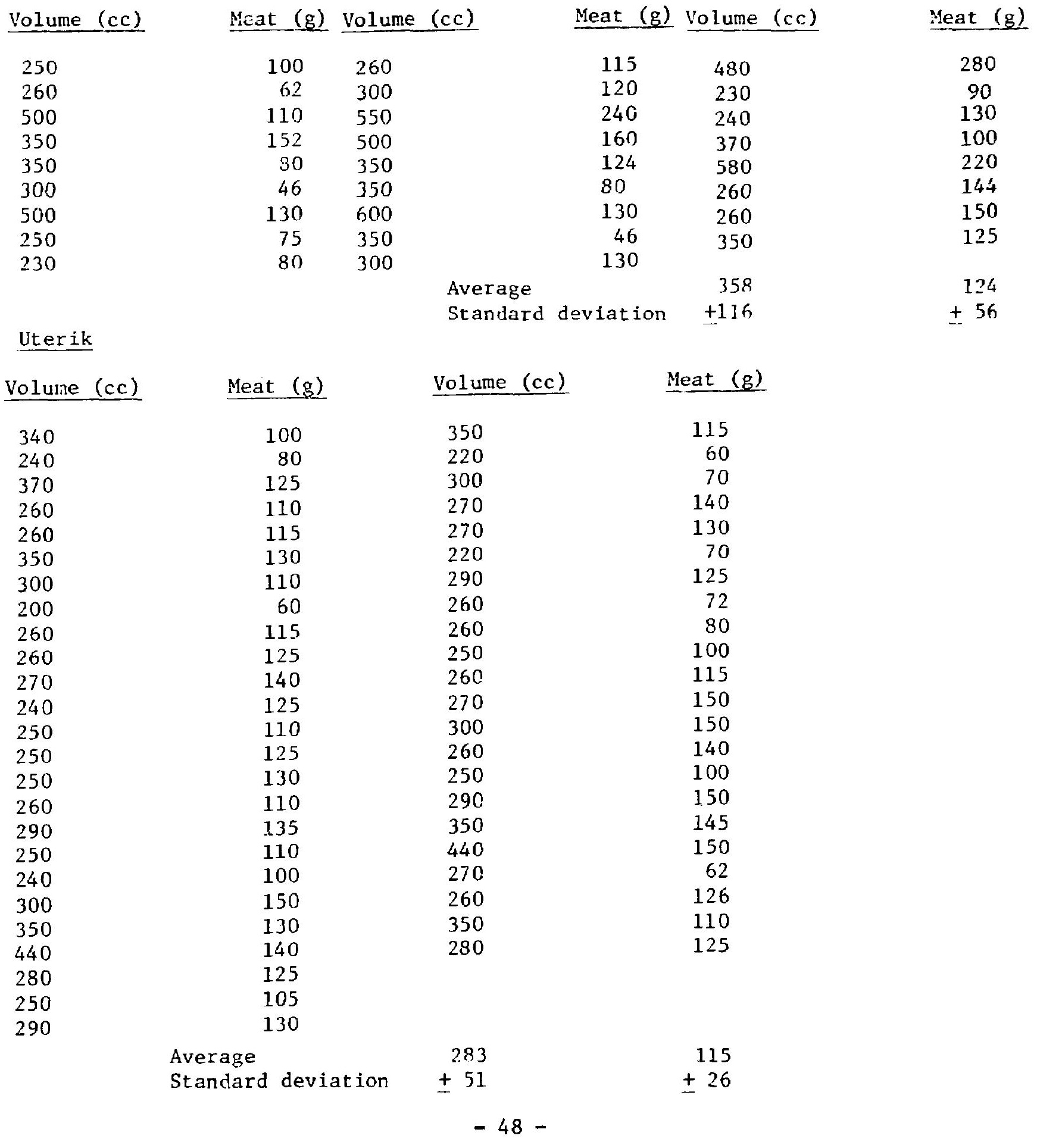




\section{COCONUTS - DRINKING}

Ailuk

\begin{tabular}{|c|c|c|c|}
\hline Volume (cc) & Meat $(\mathrm{g})$ & Volume (cc) & Meat (g) \\
\hline 430 & $11 n$ & 430 & 120 \\
\hline 380 & 35 & 620 & 165 \\
\hline 450 & 170 & 450 & 170 \\
\hline 280 & 110 & 240 & 50 \\
\hline 440 & 140 & 330 & 165 \\
\hline 180 & 45 & 370 & 110 \\
\hline 180 & 50 & 450 & 130 \\
\hline 180 & 60 & & 100 \\
\hline 180 & 55 & & \\
\hline 240 & 70 & & \\
\hline 240 & 75 & & \\
\hline 240 & 65 & & \\
\hline 240 & 60 & & \\
\hline 240 & 58 & & \\
\hline 240 & 45 & & \\
\hline 240 & 60 & & \\
\hline
\end{tabular}

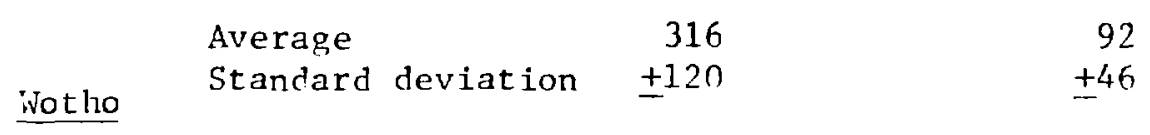

Volume (cc)

330

310

340

330
Meat (g)

95

85

100

59 $\overline{\mathrm{x}} \div 38$

$\mathrm{S}+13$
95

$+18$
Average

Standard leviation 
Coconut Data (Waini or Grating Type)

\begin{tabular}{|c|c|c|c|c|c|}
\hline No. & $\begin{array}{l}\text { Weight } \\
\text { coconut (g) }\end{array}$ & $\begin{array}{l}\text { Weight of } \\
\text { coconut meat (g) }\end{array}$ & No. & $\begin{array}{l}\text { Weight of } \\
\text { coconut }(\mathrm{g})\end{array}$ & $\begin{array}{c}\text { Weight of } \\
\text { coconut meat (g) }\end{array}$ \\
\hline 1 & 340 & 227 & 29 & 494 & 343 \\
\hline 2 & 397 & 255 & 30 & 416 & 277 \\
\hline 3 & 300 & 205 & 31 & 340 & 236 \\
\hline 4 & 360 & 253 & 32 & 465 & 282 \\
\hline 5 & 446 & 267 & 33 & $49 n$ & 350 \\
\hline 6 & 500 & 312 & 34 & 476 & 280 \\
\hline 7 & 490 & 288 & 35 & 433 & 259 \\
\hline 8 & 280 & 200 & 36 & 346 & 237 \\
\hline 9 & 400 & 250 & 37 & 490 & 306 \\
\hline 10 & 420 & 262 & 38 & 510 & 319 \\
\hline 11 & 460 & 270 & 39 & 496 & 282 \\
\hline 12 & 440 & 293 & 40 & 355 & 237 \\
\hline 13 & 400 & 267 & 41 & 418 & 271 \\
\hline 14 & 480 & 300 & 42 & 455 & 292 \\
\hline 15 & 360 & 225 & 43 & 515 & 303 \\
\hline 16 & 320 & 229 & 44 & 316 & 226 \\
\hline 17 & 380 & 238 & 45 & 296 & 206 \\
\hline 18 & 410 & 263 & 46 & 314 & 209 \\
\hline 19 & 354 & 230 & 47 & 356 & 244 \\
\hline 20 & 395 & 271 & 48 & 294 & 216 \\
\hline 21 & 375 & 257 & 49 & 456 & 275 \\
\hline 22 & 330 & 224 & 50 & 399 & 256 \\
\hline 23 & 440 & 268 & 51 & 482 & 313 \\
\hline 24 & 472 & 311 & 52 & $5 \cap 9$ & 299 \\
\hline 25 & 426 & 284 & 53 & 365 & 235 \\
\hline 26 & 386 & 280 & 54 & 492 & 319 \\
\hline 27 & 349 & 253 & 55 & 515 & 334 \\
\hline 28 & 420 & 247 & 56 & 338 & 241 \\
\hline & & $\begin{array}{l}\text { Average } \\
\text { Standard }\end{array}$ & & $\begin{array}{r}410 \\
+\quad 68 \\
\end{array}$ & $\begin{array}{r}265 \\
+\quad 36\end{array}$ \\
\hline
\end{tabular}


PANDANUS

\begin{tabular}{|c|c|c|c|}
\hline $\begin{array}{c}\text { Pandanus } \\
\text { number }\end{array}$ & $\begin{array}{l}\text { Weight }(\mathrm{g}) \\
\text { before: }\end{array}$ & $\begin{array}{l}\text { Weight (g) } \\
\text { after* }\end{array}$ & $\begin{array}{l}\text { Weight (g) } \\
\text { of food } \\
\text { eaten } \\
\end{array}$ \\
\hline 1 & 144 & 93 & 51 \\
\hline 2 & 165.5 & 98.5 & 67 \\
\hline j & 148.5 & 103.5 & 45 \\
\hline 4 & 204.5 & 140 & 64.5 \\
\hline 5 & 139.5 & 83 & 56.5 \\
\hline 6 & 151 & 107.5 & 43.5 \\
\hline 7 & 137.5 & 90 & 47.5 \\
\hline 8 & 139.5 & 88 & 51.5 \\
\hline 9 & 154 & 107 & 47 \\
\hline 10 & 157 & 108.5 & 48.5 \\
\hline 11 & 161 & 109.5 & 51.5 \\
\hline 12 & 177 & 127 & 50 \\
\hline 13 & 133.5 & 87 & 46.5 \\
\hline 14 & 289 (doubl€) & 188 & 101 \\
\hline 15 & 148 & 104 & 44 \\
\hline 16 & 155.5 & 105.5 & 50 \\
\hline 17 & 164 & 117.5 & 46.5 \\
\hline 18 & 189.5 & 131 & 58.5 \\
\hline 19 & 152 & 109.5 & 42.5 \\
\hline 20 & 131.5 & 89.5 & 42 \\
\hline 21 & 160.5 & 113.5 & 47 \\
\hline 22 & 171.5 & 123 & 48.5 \\
\hline 23 & 153.5 & 105.5 & 48 \\
\hline 24 & 142 & 102.5 & 39.5 \\
\hline 25 & 151 & 105.5 & 45.5 \\
\hline 26 & 156.5 & 116.5 & 40 \\
\hline 27 & 151.5 & 115.5 & 36 \\
\hline 28 & 127.5 & 91.5 & 36 \\
\hline 29 & 114.5 & 83.5 & 31 \\
\hline 30 & 134.5 & 82 & 52.5 \\
\hline 31 & 178 & 132 & 46 \\
\hline 32 & 186 & 139.5 & 46.5 \\
\hline 33 & 149 & 131 & 18 \\
\hline 34 & 168.5 & 122.5 & 46 \\
\hline 35 & 106 & 69 & 37 \\
\hline
\end{tabular}

*weight before + after process known as kilok method of extracting pudding from cooked pandanus

$\begin{array}{lrrr}\text { Average } & 156 & 106 & 46 \\ \text { Standard deviation } & \pm 20 & \pm 17 & \pm 9\end{array}$




\section{PANDANUS}

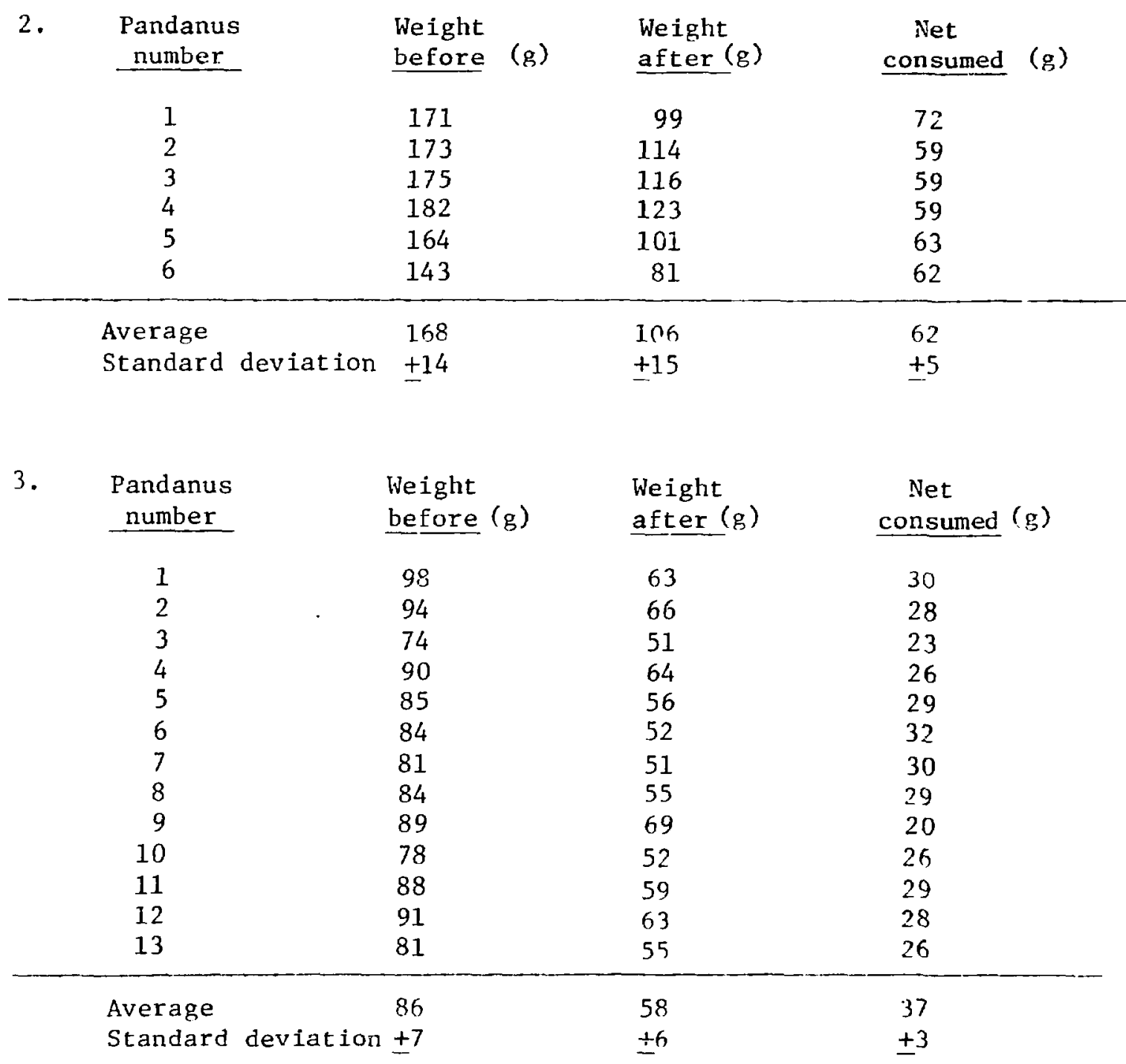


BREADFRUIT DATA

Type

Total wt. (g)

Center (unedible) (g)

Edible wt. (g)

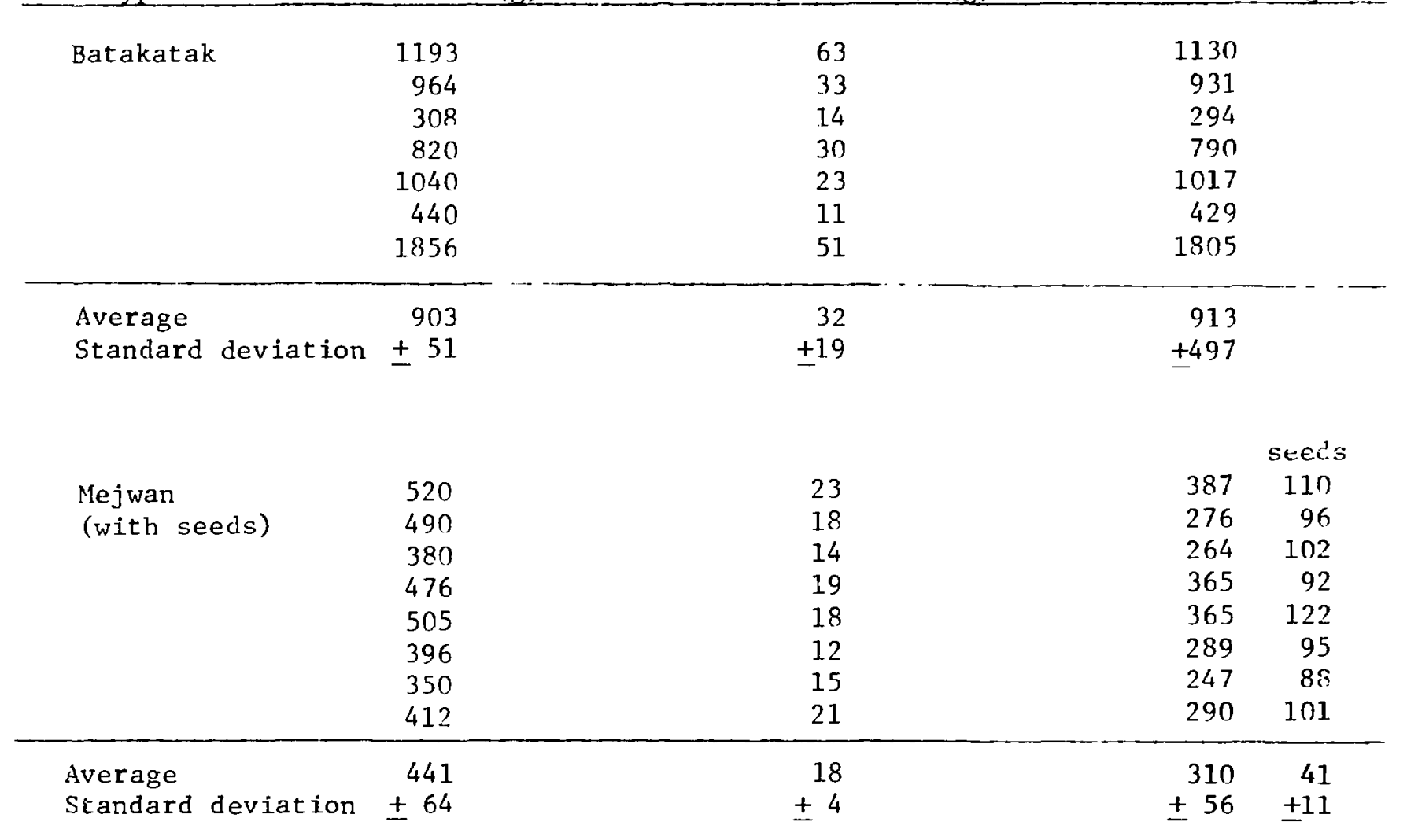


Appendix E

Types of Fish and Methods of Fishing

1. NET FISHING - LONG NET, THROWN NET

\section{Marshallese Name}

Ik kadre

Utot or dibab

or wut wot

Pajrok

Balle

Jome

Jo

Momo

Tinar

Kalemeej

Kuro

Ettou

Ioo1

Akor

Tak

Mao or Mera
Scientific Name

A fish

Chelon vaigiensus

butterfly fish

Chaetodon anriga

chub or rudder fish

Kyphosus vaigiensis

starry flounder

Platichthys stellus

goatfish

Mulloidichyhys auriflama

goat $f$ ish

Mulloidicthys samoensis

grouper

Epinephelus hexagonatus

smal1 grouper

blue spotted grouper

Cepahs lopholis argus

grouper

Epinephelus fuscogultatus

mackerel

Trachurops crumepthalmus

mullet

Crenmugil crenilabis

mullet

Chelon vaigiensis

needle fish

Belone platyura, Raphiobelone robusta

parrot fish

Scarus jonesi/sordidus
Island

Method

Rongelap - long net

Uterik - long net

Rongelap, Wotho, Ailuk

Ailuk - long net

Rongelpa, Uterik - thrown net

Rongelap - long net

Rongelap - thrown net

Wotho - not specified

Ailuk -

Rongelap, Ailuk - long net

Ailuk -

Ailuk -

Ailuk -

Rongelap - thrown net, long net

Rongelay, Wotho - long net

Uterik - long and thrown net

Rongelap, Ailuk - long net

Wotho, Ailuk 


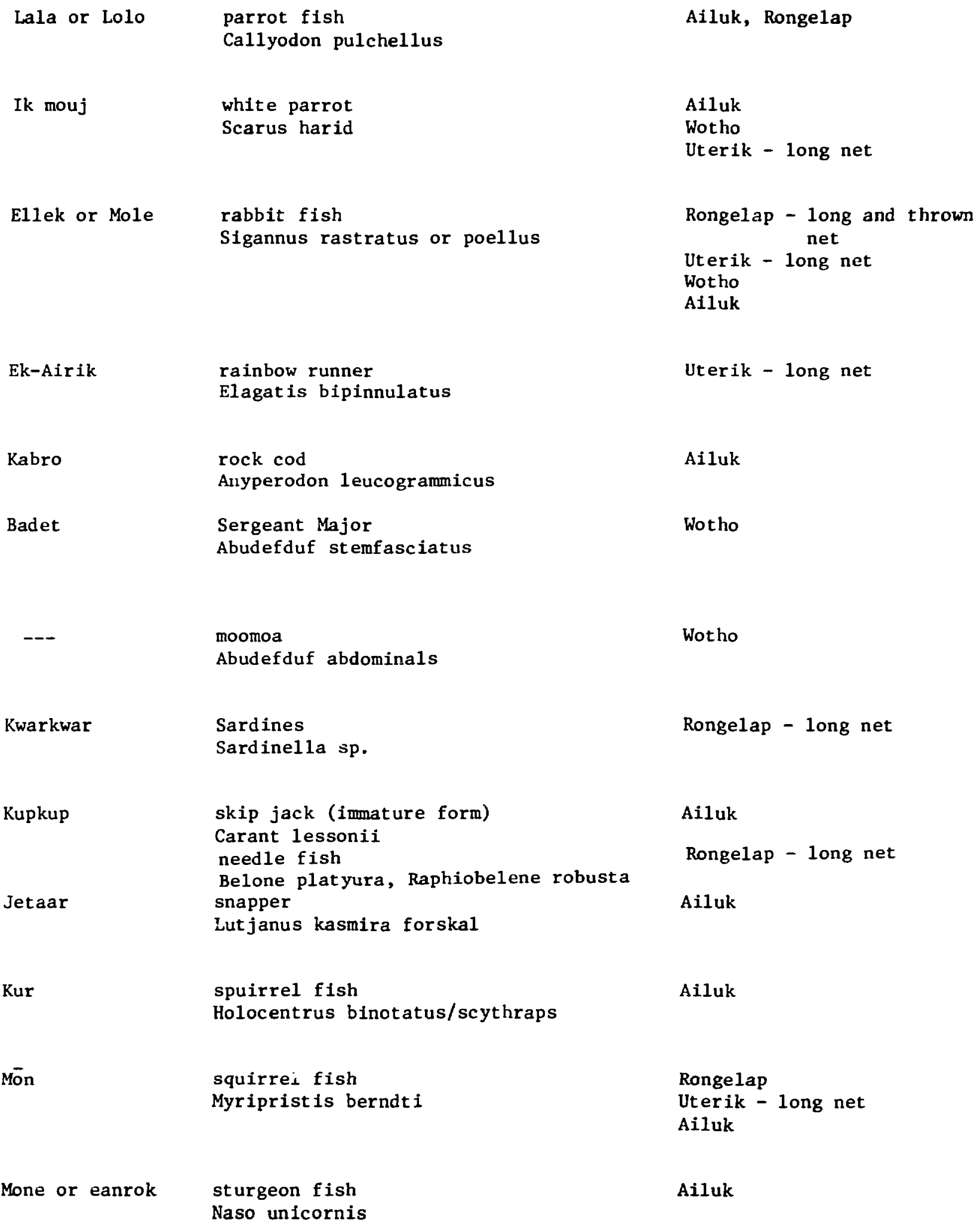


$\begin{array}{ll}\text { Kupan } & \text { banded sturgeon } \mathrm{fish} \\ \text { Acanthurus triostegus/linnaeus }\end{array}$

Tiepdo

Bub

Ae1

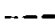

Bataklaj

Kibu

Jorot

Akuba

Debijdreka

Ebil black sturgeon fish

Acanthurus nigicans

black trigger fish

Melichthys ringens

unicorn fish

Hepatus divaceus/scheider Bloch

orange spot tang

Acanthurus olivaraceus

unicorn fish

Naso brevirostris
Rongelap - long and thrown net Uterik - long net Wotho -

Ailuk

Ailuk, Rongelap

Ailuk

Alluk.

Ailuk

Uterik - long and thrown net

Ailuk

Uterik - thrown net

Ailuk

Ailuk

Ailuk 


\section{FISHING LINE *}

Marshallese name Scientific name

Niitra or

Jure

Lejabwil

Koko

A1

Ikaidrik

Jilo

Bwebwe barracuda

Sphyraena forsteri

bonito

Katsuwanus pelamis

dolphin

Coryphoena hippurus

kingfish

rainbow runner

dogtoothed tuna

Gymnosarda nuda

tuna

Neothunus macropterus
Island

Ailuk, Wotko, Rongelap

Ailuk, Rongelap

Ailuk

Ailuk, Rongelap

Ailuk, Rongelap

Ailuk, Rongelap

Ailuk, Rongelap

*method used at oceanside (of $f$ the reef) 


\section{FISHING LINE *}

Marshallese name

Kuro

Lejebjeb

Perak

Dijin

Jato or Ikonbōn

or Jaap

Jera

Ewae or Loom

Lane or Ikbwij

Bwilak

Weo

streaker

Aprion virescens

skip jack

Caranx lessoni/crevally

unicorn sturgeon

Naso lituratus

grouper
Island

caught in deep water by lagoon or ocean

Epinephelus fuscagultatus

Ailuk, Rongelap, Uterik, Wotho

Ailuk, Rongelap (bottom fishing), Uterik, Wotho

Ailuk, Rongelap, Uterik

Ailuk, Rongelap, Wotho

Ailuk, Wotho, Rongelap (bottom fishing)

Ailuk, Uter:

Ailuk, Uterik, Rongelap

Uterik, Rongelap, Ailuk

Ailuk

Wotho, Uterik, Ailuk, Rongelap

*used in deep water (lagoon or ocean) 


\section{FISHING LINE *}

\begin{tabular}{|c|c|c|}
\hline Marshallese name & Scientific name & Island \\
\hline At-kadu & $\begin{array}{l}\text { A fish } \\
\text { Moi polydactylus }\end{array}$ & Uterik \\
\hline Kanbok & $\begin{array}{l}\text { bass } \\
\text { Variola louti }\end{array}$ & Rongelap \\
\hline Kie & $\begin{array}{l}\text { big eye or burgy } \\
\text { Monotaxis grandocul is }\end{array}$ & Rongelap, Uterik \\
\hline Dibab & $\begin{array}{l}\text { butterfly fish } \\
\text { Chaetodon ocellatus }\end{array}$ & Uterik \\
\hline Pajrok & $\begin{array}{l}\text { chub ro rudderfish } \\
\text { Kyphosis vaigiensis }\end{array}$ & Uterik, Rongelap \\
\hline Jojo & $\begin{array}{l}\text { flying fish } \\
\text { Exocoetidae sp. }\end{array}$ & Rongelpa, Uterik, Ailuk \\
\hline Jo & $\begin{array}{l}\text { goatfish } \\
\text { Mulloidichthy samoensis }\end{array}$ & Uterik \\
\hline Jome & $\begin{array}{l}\text { goatfish } \\
\text { Mulloikicthys samoensis }\end{array}$ & Uterik \\
\hline Momo & $\begin{array}{l}\text { grouper } \\
\text { Epinephelus hexagonatus }\end{array}$ & Rongelap, Uterik, Wotho \\
\hline Pako & $\begin{array}{l}\text { ground shark } \\
\text { Carcharhinus melanopterus }\end{array}$ & Uterik, Rongelap \\
\hline Lappo & $\begin{array}{l}\text { hogfish } \\
\text { Chelinus undulatus }\end{array}$ & Rongelap, Uterik \\
\hline Ioō1 & $\begin{array}{l}\text { mullet } \\
\text { Crenmugil crenilabis }\end{array}$ & Uterik \\
\hline Ikuut & $\begin{array}{l}\text { pilot fish } \\
\text { Haucrates ductor }\end{array}$ & Uterik \\
\hline
\end{tabular}




\begin{tabular}{|c|c|c|}
\hline Imin & $\begin{array}{l}\text { reef triggerfish } \\
\text { Balistopus retangulus/oculeatus }\end{array}$ & Uterik, Rongelap \\
\hline Mōn or Arōn & $\begin{array}{l}\text { squirrel fish } \\
\text { Myristis berndti }\end{array}$ & Rongelap - trolling \\
\hline Kupkup & $\begin{array}{l}\text { skip jack (immature form) } \\
\text { Caranx lessonii }\end{array}$ & Uterik \\
\hline Lojkan & shell fish & Rongelap \\
\hline Jetaar & $\begin{array}{l}\text { snapper } \\
\text { Lutjanus kasmira/forskal }\end{array}$ & Uterik, Rongelap \\
\hline Bar & snapper & Rongelap, Wotho \\
\hline Kejwar & --- & Rongelap \\
\hline Lele & $\begin{array}{l}\text { triggerfish, } \\
\text { Rhinecanthus aculeatus }\end{array}$ & $\begin{array}{l}\text { Wotho, Rongelap - bottom } \\
\text { fishing }\end{array}$ \\
\hline Jebos & --- & Uterik \\
\hline Kibu & -- & Uterik \\
\hline Melij & -- & Rongelap \\
\hline Januron & -- & Wotho \\
\hline Bokl im & -- & $\begin{array}{l}\text { lotho, Uterik, Rongelap - } \\
\text { bottom fishing }\end{array}$ \\
\hline
\end{tabular}

*used in deep water (lagoon or ocean) 


\begin{tabular}{|c|c|c|}
\hline Marshallese name & Scientific name & Island \\
\hline Pajrok & $\begin{array}{l}\text { chub ro rudderfish } \\
\text { Kyphosus vaigiensis }\end{array}$ & Ailuk \\
\hline Balle & $\begin{array}{l}\text { starry flounder } \\
\text { Platichthys stellatus }\end{array}$ & Ailuk \\
\hline Jo & $\begin{array}{l}\text { goatfish } \\
\text { Mullaoidichthys samoensis }\end{array}$ & Ailuk \\
\hline Tinar & $\begin{array}{l}\text { small grouper } \\
\text { Lutjanus kasmira forkse } 1\end{array}$ & Rongelap \\
\hline Momo & $\begin{array}{l}\text { grouper } \\
\text { Epinephelus hexangonatus }\end{array}$ & Ailuk \\
\hline Kuro & $\begin{array}{l}\text { grouper } \\
\text { Playichthys stellus }\end{array}$ & Ailuk \\
\hline Tak & $\begin{array}{l}\text { needlefish } \\
\text { Belone platyura, Raphiobelone robusta }\end{array}$ & Ailuk, Rongelap \\
\hline KupKup & $\begin{array}{l}\text { skip jack (immature form) } \\
\text { Caranx lessonini }\end{array}$ & Ailuk \\
\hline Kur & $\begin{array}{l}\text { squirrel fish } \\
\text { Holocentrus binotatus/scythrops }\end{array}$ & Ailuk \\
\hline $\begin{array}{l}\text { Monōr } \\
\text { (Arōn) }\end{array}$ & $\begin{array}{l}\text { squirrel fish } \\
\text { Myristis berndti }\end{array}$ & Ailuk, Rongelap \\
\hline Kibu & --- & Ailuk \\
\hline Akuba & -- & Ailuk \\
\hline Ebil & --- & Ailuk \\
\hline *pole fishing in & shallow water & \\
\hline
\end{tabular}


Marsha1lese name

Dep or

Eddeup

Kie

Utot or Dibab or Wutwot

Kanbök

Jawe

Pajrok

Monaknak

Bale

Jo

Jome

Tinar

Momo
Scientific name

A fish

big eye or burgy

Monotaxis grandoculis

butterfly fish

Chaetodon onriga

bass

Variola louti

giant sea bass

Promicrops lancelatus/truncatus

Plectropomus truncatus

chub or rudder fish

Kyphosus vaigiensis

file fish

Amansis carolge

starry flounder

Platichthys stellatus

goatfish

Mulloidichthys samoensis

goatfish

Mulloidicthys samoensis

small grouper

Lutjanus kasmira/forskal

grouper

Epinephelus hexagonatus
Islands

Uterik

Rongelap, Uterik

Uterik

Rongelap

Rongelap, Uterik

Rongelap, Uterik, Wotho

Uterik

Rongelap, Uterik

Uterik, Wotho

Uterik

Ailuk, Rongelap

Uterik, Wotho

cont inued 


\section{SPEARING FISH}

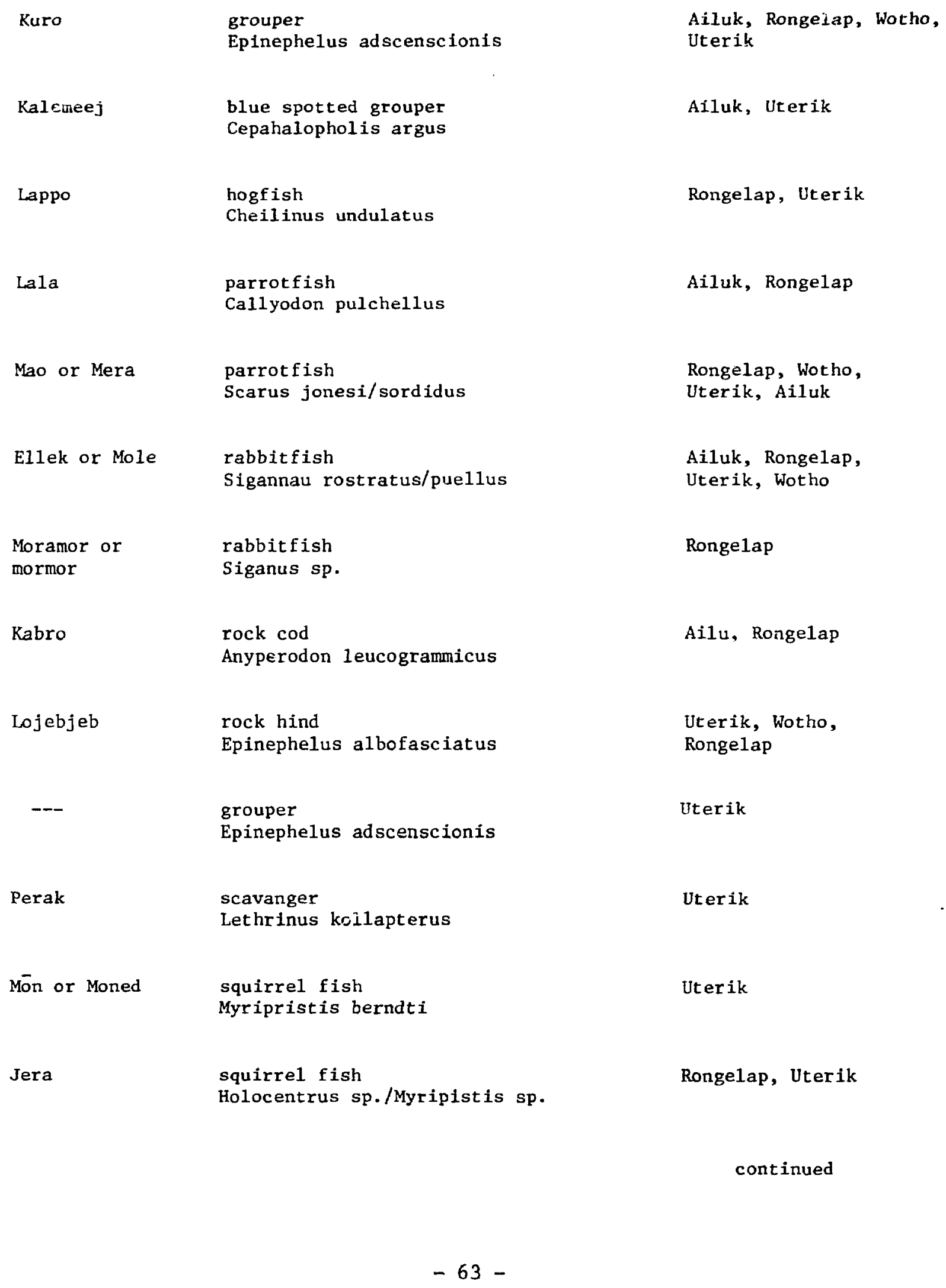




\section{SPEARING FISH}

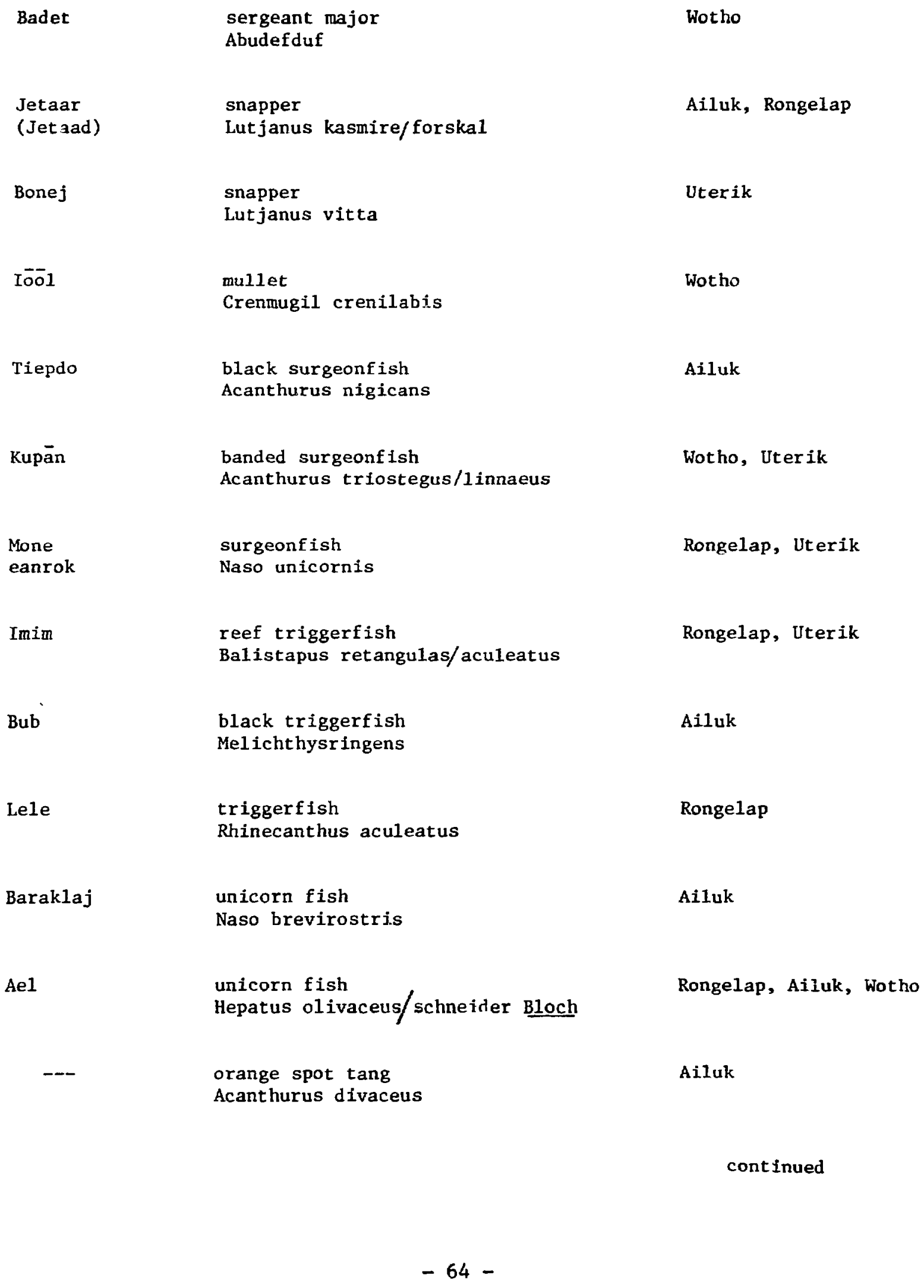




\section{SPEARING FISH}

\begin{tabular}{|c|c|c|}
\hline Bwilak & $\begin{array}{l}\text { unicorn - surgeon } \\
\text { Naso lituratus }\end{array}$ & Rongelap, Uterik \\
\hline Ik mouj & $\begin{array}{l}\text { white parrot } \\
\text { Scarus harid }\end{array}$ & $\begin{array}{l}\text { Ailuk, Rongelap, } \\
\text { Uterik, Wotho }\end{array}$ \\
\hline Jiborbor & -- & Rongelap \\
\hline Kibuj & -- & Uterik \\
\hline Jonuron & -- & Wotho \\
\hline Boklim & -- & Wotho, Rongelap \\
\hline Ieo & --- & Uterik \\
\hline Ikenae & --- & Wotho \\
\hline Pebijdreka & $-\cdots$ & Ailuk \\
\hline Karlas & --- & Uterik \\
\hline
\end{tabular}




\section{RONGELAP}

Fish poisoning from

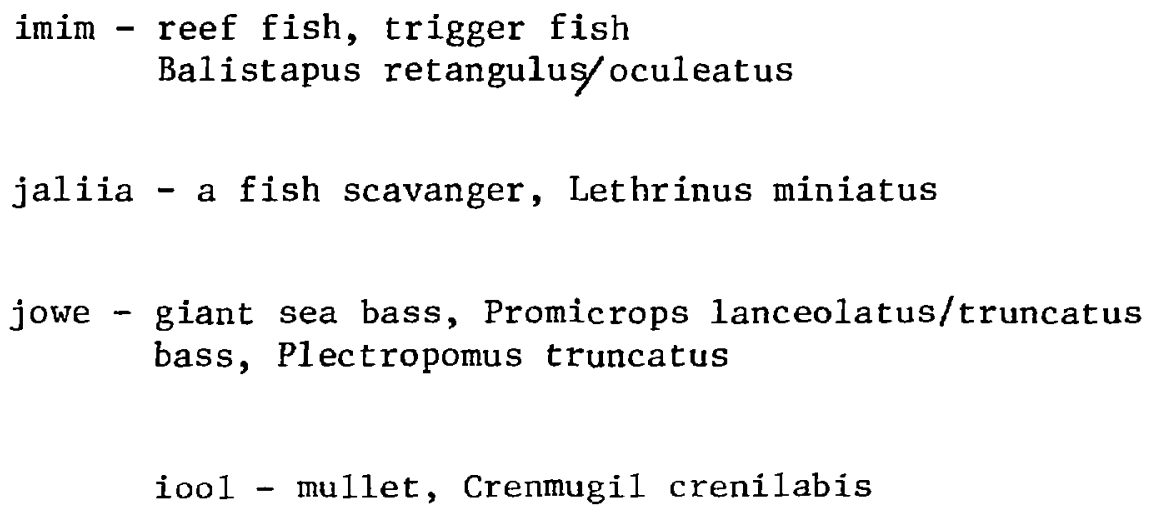

WOTHO

Fish poisoning from

mao

ekmouj

iō1

ae1

lele

ikenae 


\section{Appendix F}

School Children's Feeding Program

1. The school children's feeding program requires that each child should receive:

\section{Type A Menu}

Breakfast

Fruit - 1/2 cup

or

Fruit juice - 1 cup

Bread - 1 slice

Milk - 1 cup

Meat - 1 ounce (optional)
Lunch

Meat -2 ounces

Fruit and vegetables - 3/4 cup

Milk - 1 cup

Bread - 1 slice

Butter - 1/2 teaspoon (optional)

\section{Substitutions:}

For meat we can use any canned meat, fish, pork, chicken, shell fish, jokra, clans, turtle, eggs, and peanut butter.

Instead of bread we can use 1/2-3/4 cup of rice, taro, breadfruit, coconut meat, bananas.

Fruit and vegetables can be any of the canned fruits and vegetables, papaya, pumpliin, taro leaves, sweet potato, Chinese cabbage.

Note: Each school is allowed $\$ 100 /$ month for purchase of local food. 
2. Lunch program as carried out at the different Atolls/islands.

a. Number of school days a week - 5

b. Number of school days a year -210

c. Items and quantities

I: Breakfast

Basic

1. Fruit

or

Fruit juice

2. Bread

or

Rice

(powdered)

4. Sugar

5. Meat (canned) (fresh)

or

Fish (canned)

or

Fish (fresh)
Substituted by

Fruit cocktail, peaches

apple sauce, pineapple

orange, grape, apple

flour

macaroni, oatmeal

or

taro, breadfruit,

coconut meat, bananas

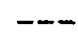

eggs (processed), peanut butter, spam, beef stew, chicken, pork mackere1, tuna

or

fish, turtle, shellfish
Amount

$57 \mathrm{~g}$

$240 \mathrm{cc}$

$30 \mathrm{~g}$

115-200 g

(cooked weight)

$15-30 \mathrm{~g}$

$30 \mathrm{~g}$ 
II. Lunch

$\underline{\text { Basic }}$

$$
\begin{aligned}
& \text { a. Meat - canned } \\
& \frac{\text { or } \text { - fresh* }}{\text { or }} \text { - Fish - canned } \\
& \text { or - fresh* }
\end{aligned}
$$

b. Fruit and vegetable

c. Milk

d. Bread

or

Oatmea 1

or

e. butter
Substituted by

Amount

spam, beef stew,

pork, chicken

mackere1, tuna

fish, shellfish, turtle

$57 \mathrm{~g}$

or

peanut butter

Fruit cocktail, peaches

applesauce, pineapple

or

mixed vegetables, peas,

tomatoes, corn, greenbeans

$\begin{array}{ll} & 240 \mathrm{cc} \\ & 29 \mathrm{~g} \\ & 114-170 \mathrm{~g} \\ \text { taro, breadfruit } & 114-170 \mathrm{~g} \\ \text { coconut meat, bananas } & \text { (cooked weight) } \\ & 8 \mathrm{~g}\end{array}$


Append $1 \times \mathrm{G}$

$T$ uphoon Rellef

Fam1ly Distribution Guldes for nonated Commodities

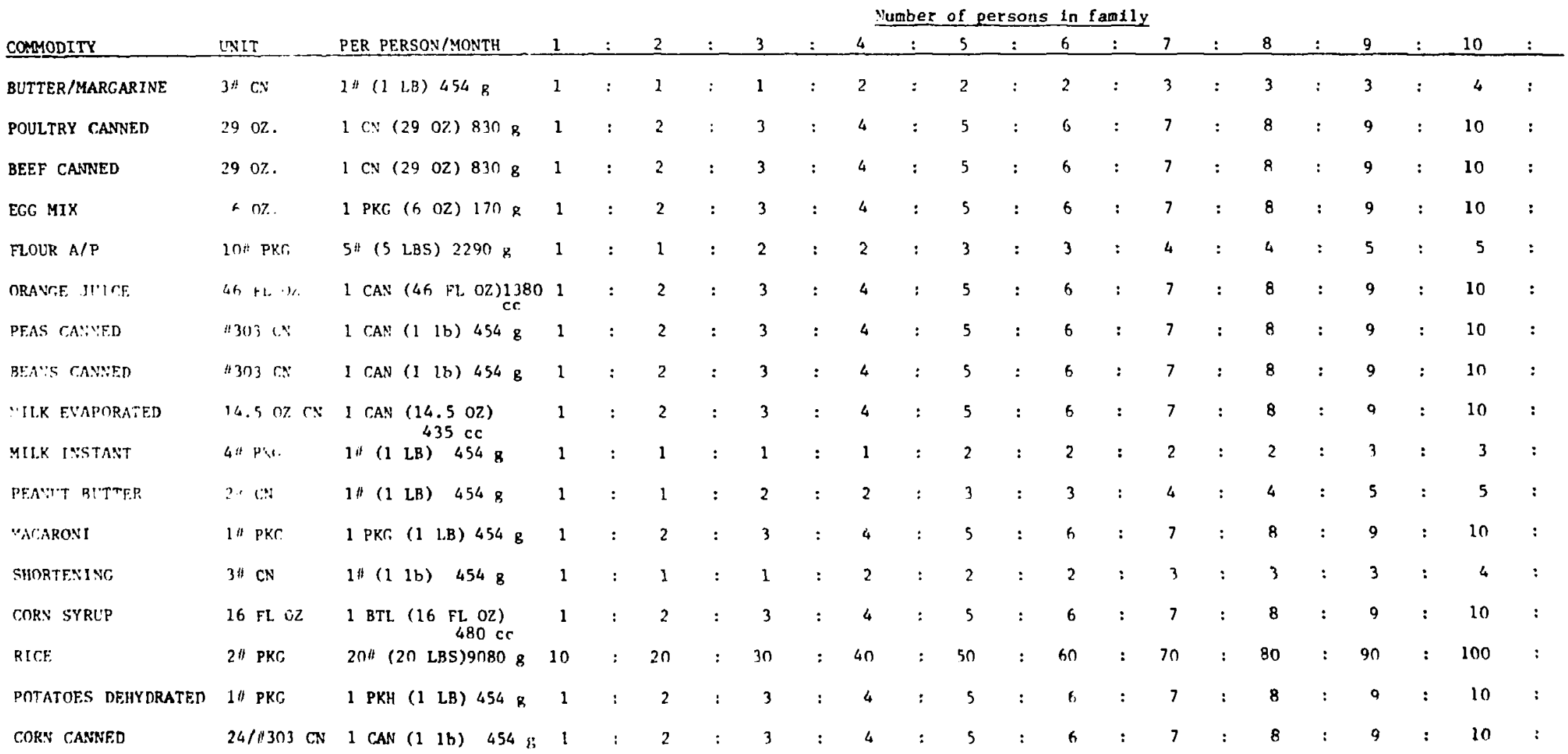

Source: Trust Territory (Majuro) 
Appendix $\mathrm{H}$

Food Supply Ships - Trip Schedule

(as carried out during 1977-1978)

\begin{tabular}{|c|c|c|c|c|c|}
\hline MONTH & SOUTHERN ATOLIS & WESTERN ATOLLS & EASTERN ATOLLS & CENTRAL ATOLLS & NORTHERN ATOLLS \\
\hline OCT & 1- FTS & 1- FTS & $-0-$ & 2- FTS & $1-$ FTS \\
\hline NOV & 1- FTS & $-0-$ & 2- FTS & 1- FTS & 1- FTS \\
\hline $\mathrm{DEC}$ & 2- FTS & 1- FTS & $-0-$ & $-0-$ & 1- FTS \\
\hline JAN & $-0-$ & $1-$ FTS & $-0-$ & $-0-$ & $1-$ FTS \\
\hline FEB & $1-\mathrm{Spc}$ & $-0-$ & $-0-$ & $1-F T S$ & 2- FTS \\
\hline MAR & 1- Spc, 1- FTS & 1- FTS & $-0-$ & 1- FTS & $-0-$ \\
\hline APR & 1- FTS & $-0-$ & 2- FTS & 1- FTS & 1- FTS \\
\hline MAY & $\begin{array}{l}\text { 1- Spc-Kili, } 1- \\
\text { FTS,1-Spc-Kili }\end{array}$ & $1-$ FTS & $-0-$ & $-0-$ & 1- FTS \\
\hline JUN & 2- FTS & 1- FTS & 1- FTS & 1- FTS & 1-Spc \\
\hline JUL & $\begin{array}{l}1-\text { FTS,1- Spc } \\
1-\mathrm{Spc}-\mathrm{K} 111\end{array}$ & 1-FTS & 1- ETS & $\begin{array}{l}\text { 1- UN Mission } \\
\text { 1- B-Pick up }\end{array}$ & $\begin{array}{l}1-\text { Spc } \\
1-\text { FTS }\end{array}$ \\
\hline AUG & $\begin{array}{l}\text { 1- Spc, Ki11, Jabor } \\
1-\mathrm{K} 111,2-\mathrm{FTS}\end{array}$ & $-0-$ & 2- FTS & 1- FTS & 1- FTS \\
\hline SEP & $\begin{array}{l}1-\text { Spc, Jabor- } \\
\text { Kili }\end{array}$ & 1- FTS & 1- FTS & 2- FTS & 1- FTS \\
\hline OCT & 1 - FTS & 1 - FTS & $1-$ FTS & $1-$ FTS & $\frac{1-\text { FTS, } 1-S_{p c}, \text { Utirik }}{\text { Rongelap }}$ \\
\hline & 13 - FTS & 9-Regular & 10-Regular & 11 -Regular & 11-Regular \\
\hline & 7- Spc & & & 2-Special & 2 -Special \\
\hline
\end{tabular}


Appendix I

\section{Private or Community Stores}

Types of Food Available*

$\begin{array}{llll}\text { Rice } & \text { Corned beef } & \text { Tang } & \text { Shoyu } \\ \text { Flour } & \text { Tuna } & \text { Milk (powdered) } & \text { Shortening } \\ \text { Sugar } & \text { Sardines } & \text { Coffee } & \text { Iodized sa]t } \\ \text { Yeast } & \text { Mackerel } & \text { Tea } & \\ \text { Biscuit } & & \text { Milk (canned) } & \\ \text { Peanut butter } & & \text { Baby food }\end{array}$

